NBER WORKING PAPER SERIES

\title{
THE REVIVED BRETTON WOODS SYSTEM'S FIRST DECADE
}

\author{
Michael P. Dooley \\ David Folkerts-Landau \\ Peter M. Garber \\ Working Paper 20454 \\ http://www.nber.org/papers/w20454
}

\author{
NATIONAL BUREAU OF ECONOMIC RESEARCH \\ 1050 Massachusetts Avenue \\ Cambridge, MA 02138 \\ September 2014
}

We are grateful to Raj Hindocha, Sahil Mahtani, and Michael Spencer for their very helpful comments and Evan Smith for expert research assistance. The views expressed herein are those of the authors and do not necessarily reflect the views of the National Bureau of Economic Research.

NBER working papers are circulated for discussion and comment purposes. They have not been peerreviewed or been subject to the review by the NBER Board of Directors that accompanies official NBER publications.

(C) 2014 by Michael P. Dooley, David Folkerts-Landau, and Peter M. Garber. All rights reserved. Short sections of text, not to exceed two paragraphs, may be quoted without explicit permission provided that full credit, including $(\mathcal{C}$ notice, is given to the source. 
The Revived Bretton Woods System's First Decade

Michael P. Dooley, David Folkerts-Landau, and Peter M. Garber

NBER Working Paper No. 20454

September 2014

JEL No. F21,F3,F43,F63

\begin{abstract}
$\underline{\text { ABSTRACT }}$
The revived Bretton Woods framework we proposed in 2003 remains a useful way to understand the international financial system. We document that the system survived the 2008 crisis. Looking forward, we argue that the system will continue to evolve as we expected. China is likely to graduate from the periphery to the center in the next few years. This graduation process could be smooth or associated with recurrent financial crises. During this transition the magnitude of net capital outflows from the periphery will continue to depress real interest rates in industrial countries at every phase of the business cycle. Finally, recent policy initiatives suggest that India is poised to replace China as the dominant periphery country.
\end{abstract}

\author{
Michael P. Dooley \\ Department of Economics \\ Engineering II \\ University of California, Santa Cruz \\ Santa Cruz, CA 95064 \\ and NBER \\ MPD@UCSC.EDU \\ David Folkerts-Landau \\ Deutsche Bank \\ Deutsche Bank AG London \\ 1 Great Winchester Street \\ London EC2 2EQ \\ United Kingdom \\ david.folkerts-landau@db.com
}

Peter M. Garber
Deutsche Bank
60 Wall Street
New York, NY 10005
peter.garber@db.com 
In a series of papers starting in 2003, we said that the current phase of the global monetary system was structured and powered by China/East Asia's export-driven growth strategy and that this impetus would last for ten or more years. ${ }^{1}$ Even after the global industrial economy finally absorbed China's labor force and China joined the other center countries, the system would reload other countries, most likely India, to play China's current role.

At the time, this portrayal of the China phase of the global monetary system, though itself novel, became quickly and widely accepted. ${ }^{2}$ What proved more controversial was our prediction that the China phase and the system itself would be more than ephemeral. Now that eleven years have passed, we return to these questions: Has this China phase of the Bretton Woods II system indeed survived for the past decade, or did the global crisis in 2008 bring the system to an end? Did our predictions for how the system would evolve match the actual outcomes? Will its China phase end soon, and if so, will it end in crisis or with a smooth transition?

We begin by presenting a summary of our views on the transition to the end of the current system and China's current reform agenda. However, the main body of the paper will document that the Bretton Woods II framework has been and remains a useful way to understand the dynamics of the international monetary system. This retrospective is the principal purpose of this note; but, prospectively, we will also discuss India's role in the next phase.

Section I will present a quick summary of our views on the transition to the end of the China phase. Section II addresses the question of whether the system's China phase has indeed survived to the present. In section III, we focus on the economic phenomena that we said were essential components and implications of the Bretton Woods II system. These include the evolution of current account imbalances, the scale and composition of gross private capital flows, international reserve accumulations, real exchange rates, real interest rates, real wages, and the absorption of massive amounts of underemployed labor in the global industrial sector.

In section IV, we examine how well these forecasts panned out. We will only briefly review the logic behind our inferences for how the system and its key components were to evolve, referring instead to our earlier work for details. Similarly, we will be sparse in presenting the disputes that broke out among researchers in open economy macroeconomics over the fate of the system.

In Section $\mathrm{V}$, we explore the case that India is becoming the next major driver of the system, taking up China's role in the periphery as China itself emerges as a center country.

\section{The 2008 Crisis and the End-Game of the System}

The 2008 financial crisis and the Great Recession that followed are often regarded as catalysts for the long-predicted end to the Bretton Woods II international monetary system. Soon after the publication of our 2003 paper, those who predicted the imminent demise of Bretton Woods II argued that the current account imbalances and large accumulations of international reserves that emerged after 2000 were

${ }^{1}$ We initially called this system the "Revived Bretton Woods System", but it quickly became known in the literature as the "Bretton Woods II System." It has been five years since we last wrote in any detail about the system; but as a reference, the new reader of this literature can use our 2008 compilation: Dooley, Folkerts-Landau, and Garber, "Asia, Interest Rates, and the Dollar", Deutsche Bank, March 12, 2008.

${ }^{2}$ As opposed to the then current notion of a nearly closed macroeconomic system in which real interest rates in the US were driven almost entirely by US or other industrial country behavior. The emerging market countries, including China, were treated strictly as small, open economies. 
unsustainable. Private and official lenders would soon doubt the willingness and ability of inveterate borrowers, particularly the United States, to repay and would cease lending. The resulting sudden stop in capital flows to the United States would generate a financial crisis similar to those that have plagued emerging markets. The predicted crisis would force a reversal of the US current account deficit; and this, in turn, would require a very large real depreciation of the dollar. The onset of the predicted crisis would be associated with a long-lasting spike up in US interest rates and a sharp decline in economic activity.

Most analysts agreed that the Bretton Woods II idea had been for a very few years a useful description of the international financial system but that this "built in" crisis would soon end its relevance. The 2008 crisis became a natural candidate for the realization of this prediction. ${ }^{3}$ But there are at least two serious problems with this interpretation. First, the 2008 crisis was neither initiated nor followed by a sudden stop of capital inflows to the United States. ${ }^{4}$ The US dollar did not sharply depreciate and US interest rates did not rise. Second, net savings continued to flow "uphill" from poor to rich countries. The pattern and even the absolute scale of key gross international capital flows have changed very little if at all, and the accumulation of international reserves has not abated.

A global crisis as severe as in 2008 has the potential to derail any international monetary arrangement, not least through its shock to national politics. However, only a careful look at the data can reveal if it marked the demise of the Bretton Woods II system's China phase. A central issue, for example, is the evolution of current account imbalances since the 2008 crisis. Current account imbalances relative to GDP for the US and China are about one-third of their average values before the 2008 crisis. But we document in the following sections that the general pattern of current account imbalances has not changed much since the crisis and that the reduced size of imbalances relative to GDP was caused partly by the lingering effects of the severe cyclical downturn. Moreover, although net capital flows from China have declined relative to China's GDP, they remain a substantial addition to the absolute real savings available to the United States and other industrial countries because of China's rapid growth.

\section{Transition to the End of the China Phase}

In 2003, we expected that the China phase of the system would eventually end. But the exit would come via the graduation of China from its export-led growth policies to consumption-based growth. The success of the export-led growth strategy would itself generate economic and political pressure to liberalize the internal financial system and access to external financial markets and to implement market-determined exchange rates. In this regard, we agreed with the mainstream view of China's ultimate developmental destination.

However, because of the large amount of underemployed labor to absorb, we estimated that the China phase of the Bretton Woods II framework would be useful for at least 10 years and possibly much longer. This informed us that this phase was at least as sustainable as was the Europe-Japan phase of the original Bretton Woods system during its convertible current account stage, 1958-1971.5 We argued that the

\footnotetext{
3 See Obstfeld, Maurice \& Rogoff, Kenneth, 2009. "Global imbalances and the financial crisis: products of common causes," Proceedings, Federal Reserve Bank of San Francisco, issue Oct, pages 131-172.

${ }^{4}$ Ironically, this predicted catastrophe is exactly what befell the peripheral countries in the euro zone, whose currency, given US imbalances, was supposed to displace the dollar as the strong, primary reserve currency.

5 All international monetary systems have been unsustainable in practice, so this frequently invoked characterization has been rhetoric that added little to our understanding of how the system would evolve. The important question for any international monetary system is how long it will last before it shifts into a different international monetary system to resolve a different international macroeconomic problem.
} 
end-game associated with China's graduation to the center could be a smooth transition as it abandoned export-led growth and financial repression. There would be no necessary attendant crisis. But we also warned that financial liberalization, which inevitably reveals misdirected investment, could itself be a fertile ground for financial crises even if properly managed.

We claimed that as the stock of cheap labor in China was absorbed, the real wage in the industrial sector would rise via rapid and persistent nominal wage increases and a less rapid, appreciating crawling peg of the renminbi. Along with comparatively low inflation, the consequent real exchange rate appreciation would gradually reduce the current account surplus. As the exchange rate reached equilibrium with no further intervention, the capital account would be opened and the domestic financial sector would be liberalized. The economy would then seek another source of growth via a more efficient allocation of capital toward consumption-oriented industries. Domestic and foreign real interest rates would converge. Again, this terminal destination, if not the dynamics, matched the conventional view.

Figure 1 shows that as expected there has been a gradual but important change in real exchange rates. From 2004 through 2014, the trade weighted real exchange rate for China appreciated by about $30 \%{ }^{6}$ From 2005 to the present, the inflation adjusted bilateral rate against the dollar appreciated about $40 \%$.

Figure 1: China Real Effective Exchange Rate

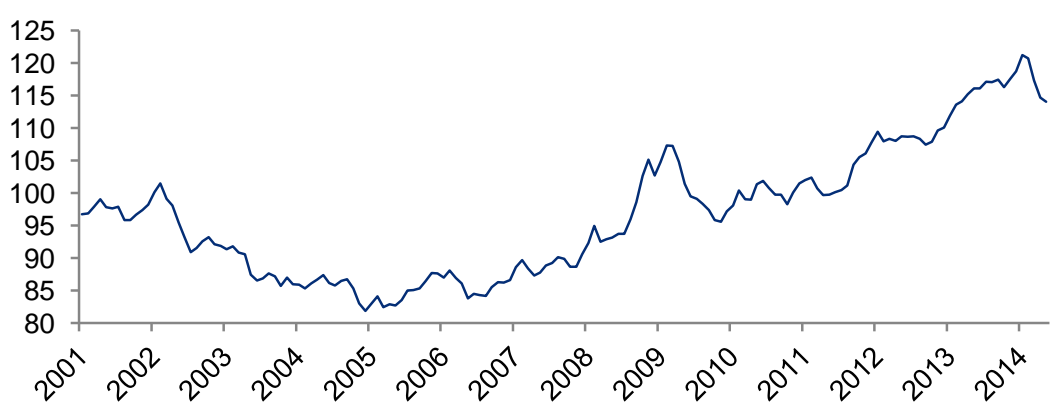

Source: BIS, Deutsche Bank Research

Simultaneously, China's current account surplus has indeed fallen relative to its GDP as the real exchange rate has risen, as indicated in Figure 2. From an average of 5.9\% from 2002 through 2008, it reached a low of $1.9 \%$ of GDP in 2011, moved up to $2.6 \%$ in 2012 , and then fell to $2 \%$ in 2013. This decline in the current account/GDP ratio can be attributed partly to the cyclical fall in foreign absorption resulting from the severe recessions and slow recoveries in industrial countries. The largest single decline came in 2009 with the severe global recession, but the post- 2008 fall also coincided with the large post-2008 appreciation of the real effective exchange rate. Nevertheless, the IMF projects that the current account/GDP ratio may rise to $3 \%$ by 2019 , driven by accelerating growth in industrial countries. ${ }^{7}$

\footnotetext{
6 The BIS REER is based on relative CPIs rather than unit labor costs. CPI inflation in China has averaged $2.6 \%$ since 2002 while nominal wage growth has averaged $14 \%$, so these data understate the real appreciation in wages.

7 Our view is that the accumulated current account surplus provides collateral to secure FDI inflows. See Section IV for details. Figure 12 indicates that the diminished current account surpluses after 2008 were still sufficient to serve this role.
} 
Figure 2: China Current Account, in \%GDP and in \$US

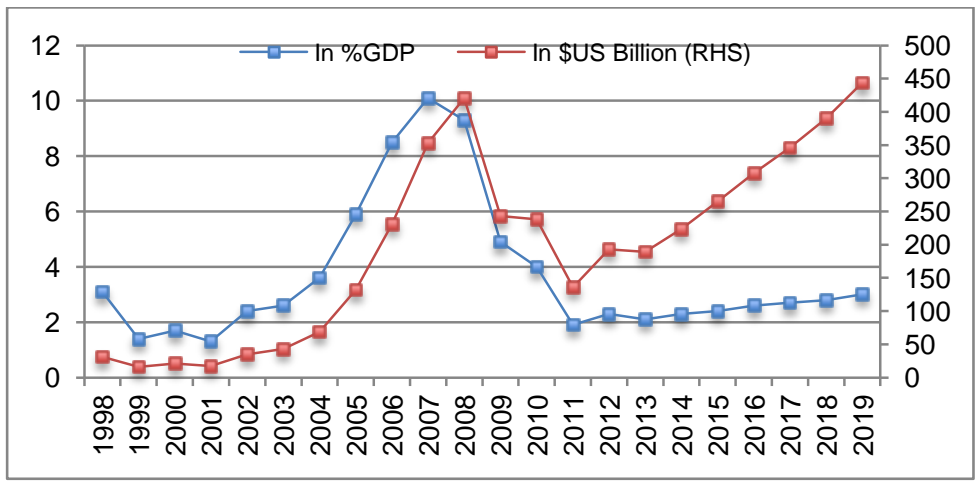

Source: IMF WEO, April 2014, Deutsche Bank Research

\section{End-Game scenarios}

Recent policy decisions in China indicate that the end-game issues are likely to materialize over the next several years. In the remarkable policy shift emerging from the Third Plenum in November 2013, Chinese authorities stated the intention of reversing the policies that in effect established China's role in Bretton Woods II. ${ }^{8}$ They also have expressed a view that the exchange rate is near equilibrium and the exportdriven development policy is near its end. ${ }^{9}$ However, senior officials still speak in terms of several more years before the reforms are fully implemented.

\section{Financial Market Reform}

Initial financial reforms aim to liberalize interest rates by raising the maximum bank deposit rate until this control ceases to constrain bank behavior and to expand the access of private sector firms to bank loans. This has already progressed via the official tolerance of the wealth management products and the shadow banking system, which is being regularized. Eventually, the favored access of the State Owned Enterprises to bank loans will be eliminated so that this sector can be rationalized.

The opening of the capital account and ending of exchange market intervention will end the official sector export of capital. But the response to this from the private sector will probably be an expanded export of capital as firms and individuals seek diversification and security for their wealth. These private outflows will likely exceed at first the inflows arising from the greater access to China permitted to foreign capital. ${ }^{10}$ If the new net outflows more than offset the then-ended official intervention, the exchange rate would tend to depreciate. In this case, the net capital exports from China would continue, and there would be continued downward pressure on the real interest rates in industrial countries.

Moreover, with the long-favorable interest carry and the anticipation that the RMB would generally appreciate, speculative capital has continually sought to penetrate the capital controls. Such capital inflows likely will abruptly reverse once the foreign exchange intervention and financial repression end, reducing expectations of further currency gains. Such a sudden, reversal would cause a sharp depreciation in the

\footnotetext{
${ }^{8}$ For a list of reforms that emerged in the succeeding seven months, see Shi and Spencer, July 15, 2014.

9 This view was expressed already in 2011 when China's current account surplus fell to $1.9 \%$ of GDP. See IMF 2013 Article IV Consultation: "Authorities Views: ...They considered that the exchange rate was close to its equilibrium value." p. 31. Since mid-2011, the RMB has appreciated as much as another $7 \%$ against the US dollar and the real effective exchange rate has appreciated by as much as $17 \%$.
}

10 See Bayoumi and Ohnsorge, August 2013. 
"equilibrium" exchange rate, unless this foreseeable, one-off outflow were met by a massive one-off sale of international reserves. ${ }^{11}$

\section{Labor Market and Land Reform}

China's Third Plenum structural reforms, with their intention of transforming consumption patterns in China, will not end with financial sector reforms but will also have a profound effect on labor markets. Later in the sequence of reforms, occupants of rural land may be allowed to sell their rights directly, thereby creating instant wealth for the rural population by removing local party bosses from intermediating the shift of land to developers. This could increase the consumption demands of holders of land rights and facilitate a shift toward a consumption-based growth model. ${ }^{12}$ Another reform will also release them to move to the cities. ${ }^{13}$ Since they would no longer need to occupy their plots to reap the flow income from them, this may release more than 200 million more people to move to the cities, which exceeds the 150 million rural migrants of the last thirty years. ${ }^{14}$

Two possible dynamics can arise to absorb this influx of extra labor. First, China's rapidly aging population will likely demand increasing amounts of services. The advent of a new, large labor force of low-skilled workers will occur at just the right moment to satisfy this demand. The release of this extra labor into the cities is then consistent with the shift to a consumption-based growth model, with the high real exchange rate ratifying the increased flow to the service sector.

Alternatively, it is not certain that the demographically-driven, increased demand for service workers in non-tradable industries can absorb the increase in labor supply. Part of this surge of workers would then enter the export sector at lower wages, which may partly restore the cheap labor basis of China's role in the Bretton Woods II system.

If employment of this new crowd in the cities again becomes the policy priority, intervention may have to begin again, along with capital exports and further downward pressure on global real interest rates. However, this time maximum pressure probably would finally congeal in industrial countries to block this surge in imports, so a larger outlet for trade would have to be found in less developed countries.

\section{Has the System Survived for the Past Decade?}

Our straightforward answer is yes. The staff of the IMF, an institution that has considered the Bretton Woods II system a threat to economic stability, makes the case for us. Below are a few quotations from the IMF's 2013 Article IV Consultation for China and from its recent book, China's Economy in Transition.

\section{On the outlook for current accounts:}

"In contrast to domestic rebalancing, substantial progress has been made in external rebalancing, and the current account surplus remains well below the 2007 peak of 10 percent of GDP. In the staff's baseline scenario, the current account surplus gradually

11 If it occurs, this one last intervention would be consistent with the crisis scenarios of first generation models of speculative attack against a strong, pegged currency, since the accumulation of reserves was partly the result of the hot money inflow. This would be the appropriate policy response if the authorities seriously want to prevent destabilization of what they regard as the equilibrium exchange rate. Another part of this inflow, however, has been a result of the de facto subsidization of the internationalization of the RMB as a major currency for denomination and settlement of transactions. Not a necessary part of internationalization, these goals suggest a geopolitical ambition. See Garber (2011).

12 See Spencer, November 8, 2013, p. 10.

13 The Urbanization Plan unveiled in March 2014 envisions allowing 100 million more people into urban areas, preferably towns and small cities, under the Hukou system in the next seven years, as compared to 50 million in the last seven years. Shi and Spencer, p. 6.

14 This reflects some combination of about 180 million remaining in surplus rural labor and 60 million "left behind" children. See Spencer, November 8, 2013, p. 10 and November 16, 2012, p. 6. 
rises to about 4 percent of GDP by 2018. This assumes a gradual recovery in global demand (consistent with the WEO projection), a constant real effective exchange rate (REER), and limited progress on domestic rebalancing in China." (2013 Article IV, p. 9)

"Undoubtedly, the shrinking external imbalance has been directly influenced by the collapse in external demand when the global financial crisis broke and the subsequent weak recovery. But other factors also appear to be at work, including changes in the terms of trade, a gradual appreciation of the renminbi, and a step increase in investment..." (Transition, p. 3.)

"Furthermore, relative to the size of the world economy, the rapid growth in the Chinese economy would indicate an increase in the current account to .6 percent of global GDP in the medium term from .2 percent in $2012 \ldots$ By this metric, the current account surplus is far from negligible..." (Transition, p. 22.)

“The decline in China's external surplus has been impressive and should be welcomed. However, this adjustment has largely been the result of very high levels of investment, a weak global environment, and an increased pace of commodity prices that outstrips the rising price of Chinese manufactured goods. Although all three of these factors are likely to continue to put downward pressure on the external imbalance, the 'rebalancing' in China advocated by the IMF over the past several years is not occurring." (Transition, p. 23.)

On export-led growth:

"Overall, staff considers that the renminbi remains moderately undervalued against a broad basket of currencies. Given the assessment of the renminbi as moderately undervalued, greater flexibility is likely to result in some further real appreciation of the renminbi over time, which will help with domestic rebalancing by making investment in non-tradables more attractive and boosting household purchasing power." (2014 Article IV), p. 21. “...this [the IMF's model] implies a current account gap of about 1-3 percent of GDP-equivalent to RMB undervaluation of about 4-12 percent. "(2013 Article IV, p. 28).

"The continued reliance on investment raises questions about how durable the compression in the external surplus will be and whether the current growth model, which has had unprecedented success in lifting about 500 million people out of poverty during the last three decades, is sustainable. In a nutshell, even as external imbalances appear to be receding, domestic imbalances seem to be on the rise. ...Alternatively, if final domestic demand is not forthcoming, Chinese firms may look outward and push the excess capacity on the world markets at the risk of depressing prices and triggering retaliatory trade action." (Transition, p. 3).

\section{On reserve accumulation:}

"Last year [2012], the surplus [in the balance of payments] edged up to $2 \frac{1}{4}$ percent of GDP, and it is expected to remain broadly unchanged this year...data through May 2013 indicate a resumption in net capital inflows. Purchase of foreign exchange reserves has also increased and amounted to US $\$ 157$ billion in the first quarter of this year, compared to US $\$ 97$ billion during all of 2012." (2013 Article IV, p. 6).

On capital mobility:

"Despite pervasive capital controls, capital flows have been considerable. ...Nonetheless, the capital controls appear to be binding." (2013 Article IV, p. 29).

On the end game:

"Time is running out on the current model which has relied on extensive growthfactor accumulation and relocation of labor from the countryside to factories." (2013 Article IV, p. 21).

“China's growth miracle has thus far relied heavily on absorbing excess labor from the countryside into factories in export-oriented manufacturing. Although China still has a 
pool of surplus labor and is not expected to reach the Lewis Turning Point... until about 2020, time is running out on when the existing framework can be modified with relatively low adjustment costs." (Transition, p. 4).

These passages indicate that Fund staff thought in mid-2013 that China then had a current account surplus of $2 \%$ of GDP and would still have a surplus of $4 \%$ of GDP in 2018 as absorption in industrial countries improves. ${ }^{15}$ They also thought that China's exchange rate is undervalued by $4 \%$ to $12 \%$, and its capital controls are still binding. Fund staff also believes that the current growth model has relied on factor accumulation and the relocation of labor from the countryside to factories and notes that China is still intervening heavily in exchange markets. This is a near-complete outline of the salient features of the Bretton Woods II system. Clearly, the IMF Staff forecast is consistent with the view that the China phase of the Bretton Woods II system is still operating. However, as has been the case for many years, the Fund staff also predicts that China's role in the system is coming to an end, i.e. its time is running out.

\section{Implications of the Bretton Woods II System}

This section provides our main inferences starting from ten years ago (principally from 2003-5) about how the system would function in its China phase. For specific references to and quotations from the papers that exposited the bullet items, see the Appendix.

General: Domestic labor markets and export-led growth.

- The Bretton Woods II international monetary system's China phase emerged as a solution to the problem of the integration of China into the global industrial economy.

- This phase of the system would last for ten or more years after 2003.

- For China, the pressing political goal of redeploying its underutilized, employable labor into more productive work was paramount. It had at least 200 million such workers and would absorb 10-20 million of them per year-the source of our 10year minimum for the duration of the system's China phase.

- Only part of the increase in employment would come directly through export industries; but to work successfully, the system depended on China's ability to maintain an undervalued exchange rate. This in turn required China's willingness to accumulate international reserves and net foreign assets. Financial repression would help maintain the undervalued exchange rate by eliminating the usual link between undervalued exchange rates and domestic inflation. Controls would limit the private capital flows that would normally be associated with an obviously undervalued exchange rate.

- China would overcome the normal protectionist resistance in industrial countries to an export-led development strategy by inviting foreign capital via FDI to collect much of the rent from employing low-wage Chinese labor, thereby splitting the interests of industrial country labor and capital. China would receive foreign management techniques and up-to-date product specifications and production technology in return, and its foreign markets would be unhindered by protectionism.

- Even when China becomes a center country, India will adopt China's exportdriven growth strategy; and the system will reload.

Current and Capital Account Flows, Foreign Exchange Reserves, and Inflation.

- To maintain its role in the system China must export rather than import capital on net because of a need to provide collateral against geopolitical and other country

15 This was revised down to 3\% in the April 2014 WEO data. 
risks. Such net outflows mainly in the form of USD foreign exchange reserves were the necessary condition to support the large gross FDI inflows that underpinned the development strategy.

- The "uphill flow" of capital on a macro-economic level for such a long time is an obvious and dramatic refutation of the standard textbook model of international macroeconomics. ${ }^{16}$

- The large and growing US current account deficits resulted from the large volume of foreign savings pushing in, as indicated by the declining US real interest rates, and not from US "profligacy"

- There would be no limit on the amount of foreign exchange reserves that China would acquire to keep the system going.

- Any losses on these reserves arising from an appreciating RMB or negative carry would be of strictly secondary concern.

- Any attempt to diversify its foreign exchange reserves by holding a smaller fraction of US dollars would be self-defeating and would result in its acquiring even more reserves overall. In particular, China would continue accumulating USD-denominated reserves.

- China would control any inflation arising from its undervalued currency by various forms of financial repression, specifically by raising required reserves against bank deposits and pushing low interest financing bills into banks.

- Especially in Asia but elsewhere as well, other countries that adopted the exportdriven growth strategy would likewise acquire large amounts of foreign exchange reserves. Other EM countries would have to join the peg or managed float or else be frozen out of exports via appreciation of their own currencies.

Global Real Interest Rates.

- China had become a large country; in particular, its policies of exporting its savings on net had a large impact on global long-term real interest rates. Global forces from outside of the industrial countries now determined the long-term real interest rate, not behavior in the US and other industrial countries alone.

- Globally, long-term real interest rates would be unusually low for the duration of the system and across all phases of the business cycle.

- Remarkably, the access of foreign capital to cheap Chinese labor would not increase the cost of capital in the industrial countries as large amounts of FDI moved to China. China's high savings and its need to provide collateral meant that this labor force in effect would be thrown into the industrial world carrying its own capital. The role of the international financial system in this is efficiently to allocate this part of China's savings to productive investments.

Industrial Country Exchange Rates.

- When the China phase of the system finally ended, there would be no US exchange rate crisis; nor would real interest rates spike.

- In 2003, we thought that the euro, then at parity, would appreciate against the USD. By 2005, we concluded that the euro had appreciated enough in the previous few years to reflect the financial market's learning about how the system worked. From 2005, onward, therefore, the euro and the dollar would move together against the managed appreciation of the RMB, except for asynchronous business cycles.

- After its massive 2003-4 exchange market interventions, Japan would intervene again if the yen again appreciated significantly.

16 This "uphill flow" has been known at least since Lucas (1990). But the Bretton Woods II framework moved the idea into the macroeconomic and geopolitical domain. 
- The euro zone might have to join the system and undervalue its currency to prevent its labor force's suffering from too much of a dislocation. This did not happen.

Labor Market Supply Effects in China, the US, and Other Industrial Countries

- The US would take no serious action to protect its industrial workers.

- The euro zone would take serious action to protect its industrial workers. This certainly did not happen.

- In China, an undervalued exchange rate was also a control valve in releasing agricultural labor. The greater the undervaluation, the higher would be the prices of agricultural imports and the slower the release of rural labor to the industrial sector.

Transition to the End of the China Phase.

- Over the long term, rising real wages in China and an appreciating exchange rate for the RMB would eventually bring the RMB to exchange rate equilibrium in which the continued use of controls and intervention in foreign exchange markets would be seen as a hindrance.

- In preparation for its transformation into a center country, China would then implement a gradual lifting of capital and exchange controls and an internal financial reform.

- China would then join the other major industrial economies as a center country with a floating currency, maintain open capital accounts, and a shift to consumption-based growth.

\section{How Did These Forecasts Pan Out During the Last 10 Years?}

\section{General: Domestic labor markets and export-led growth}

\section{Labor Force Allocation in China}

A large number of Chinese workers have been absorbed into the industrial and service sectors. In 2003, we estimated that 200 million workers were available for employment in the modern industrial sectors and the services that catered to these sectors. Figure 3 shows estimates of total employment in agriculture (and mining), manufacturing (and construction) and services from 1990-2013. These data suggest that about three-quarters (153 million) of the sectoral shift we thought was possible had occurred between end-2002 and 2011. The 72 million increase in manufacturing employment from 2002 to 2013 compares to total manufacturing employment for the US today of about 12 million. ${ }^{17}$

17 See Spencer, November 16, 2012, pp. 5-6 on the difficulties in interpreting these aggregate data. Given a rationalization of the use of agricultural labor, there remains even now a potential 180 million surplus workers. 
Figure 3: China: Employment by Sector, Million Workers

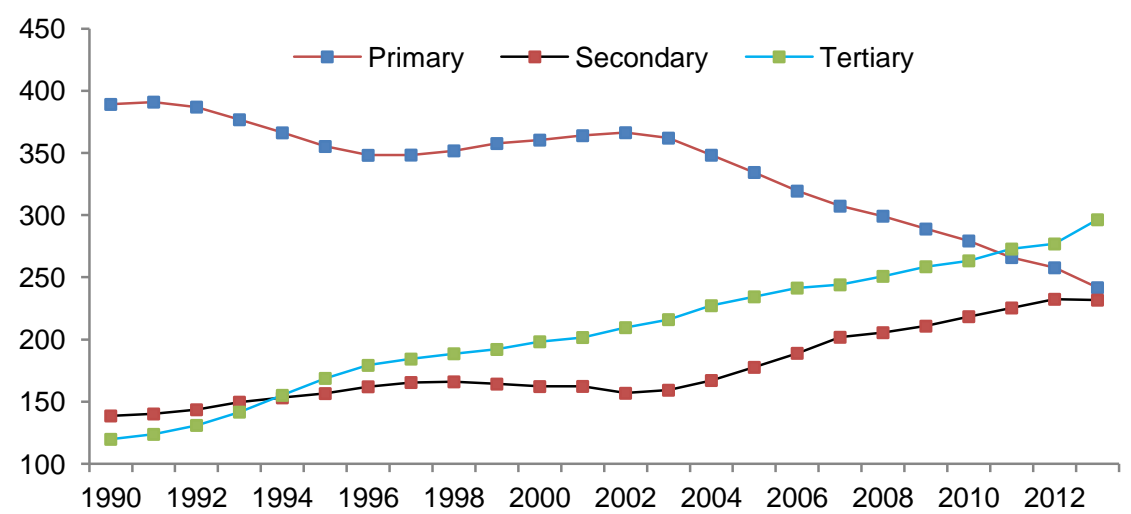

Source: CEIC, Deutsche Bank Research

\section{Export-driven growth.}

Gross exports played a large role in driving these changes in the labor market. Merchandise export growth in constant 2005 USD terms averaged 21\% per year from 2002-2007 before falling to minus $10 \%$ during the 2008-2009 recession. In 2010, merchandise export volume jumped by 28\%, and from 2011-2013, such gross export growth averaged about 8 percent. ${ }^{18}$ Figure 4 shows that as a percentage of world exports, China's share more than doubled from 5\% to 11.7\% from 2002 through 2013.

Figure 4: China: Merchandise Exports as \% of World Exports

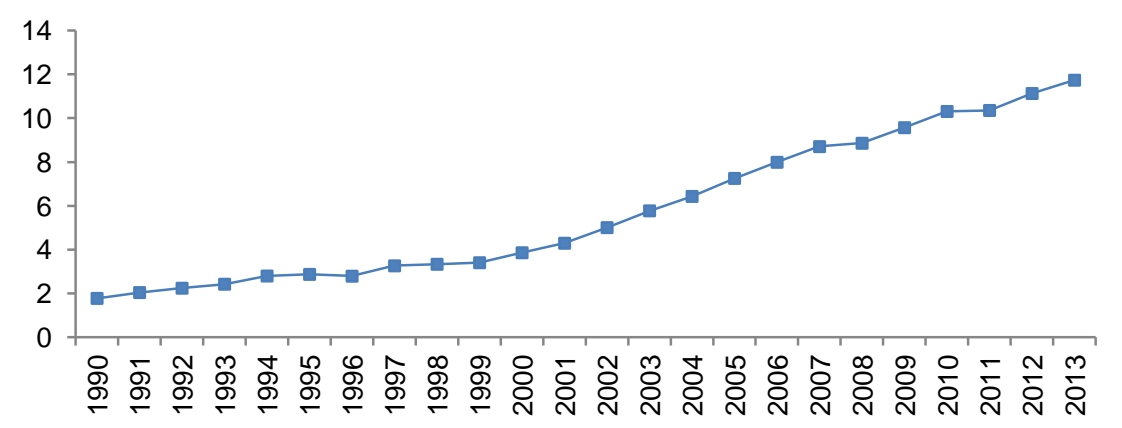

Source: UNCADStat, Deutsche Bank Research

Gross exports should be distinguished from net exports, which are the main component of the current account surplus. From the contribution of net exports to GDP growth shown in Figure 5, two points stand out. Net exports are an important component of GDP growth; but, overall, their primary role is to underpin investment flows to productive activities via FDI. The principal and consistent drivers of GDP growth in China are investment and consumption. The contribution of gross export markets is to direct investment into a capital stock that is competitive in world markets.

\footnotetext{
18 The 2013 numbers are clouded by the invoicing problems that arose in 2013 as a means for
} speculative inflows to evade capital controls. 
Figure 5: China: Contribution to Growth of Net Exports, Investment, and

Consumption

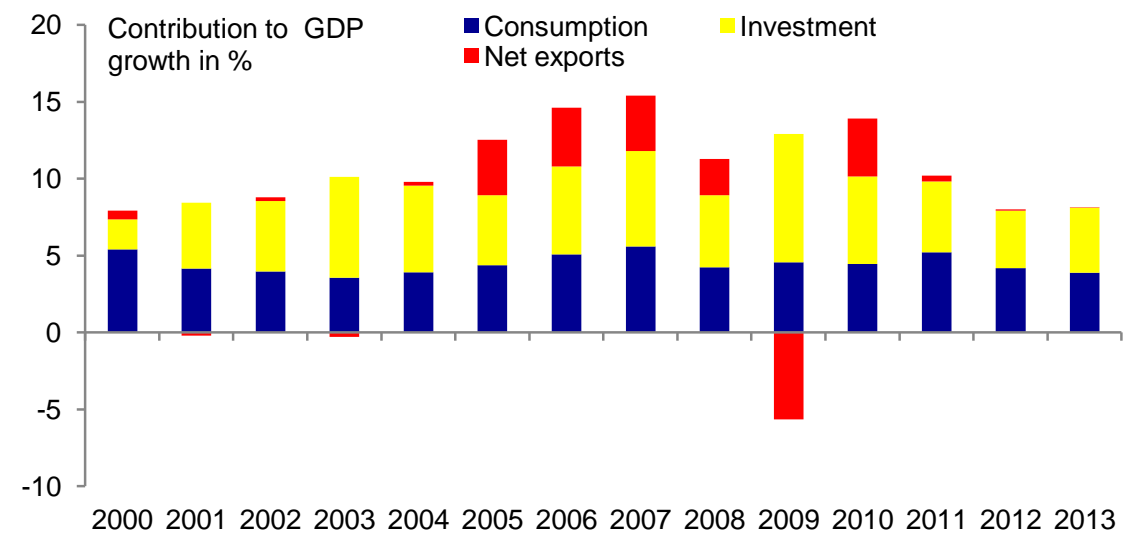

Source: World Bank, Deutsche Bank Research

Current and Capital Account Flows, Foreign Exchange Reserves and and Inflation.

\section{Current Account.}

Figure 6 shows the two important features of current account imbalances relative to global GDP, before and after the 2008 crisis. First, surplus and deficit regions' imbalances declined after the crisis and have remained at about one-half of their previous levels. Second, there have been almost no changes in the relative contribution of each region to imbalances. For example, scaling its current account deficit to the total of all deficits globally, the US's relative position has not changed at all. The same is true of China plus emerging market Asia's share in the total current accounts of surplus regions. Finally, the China-US relationship remains the dominant empirical regularity.

\section{Figure 6: Current Account Imbalances/ World GDP by Country or Region}

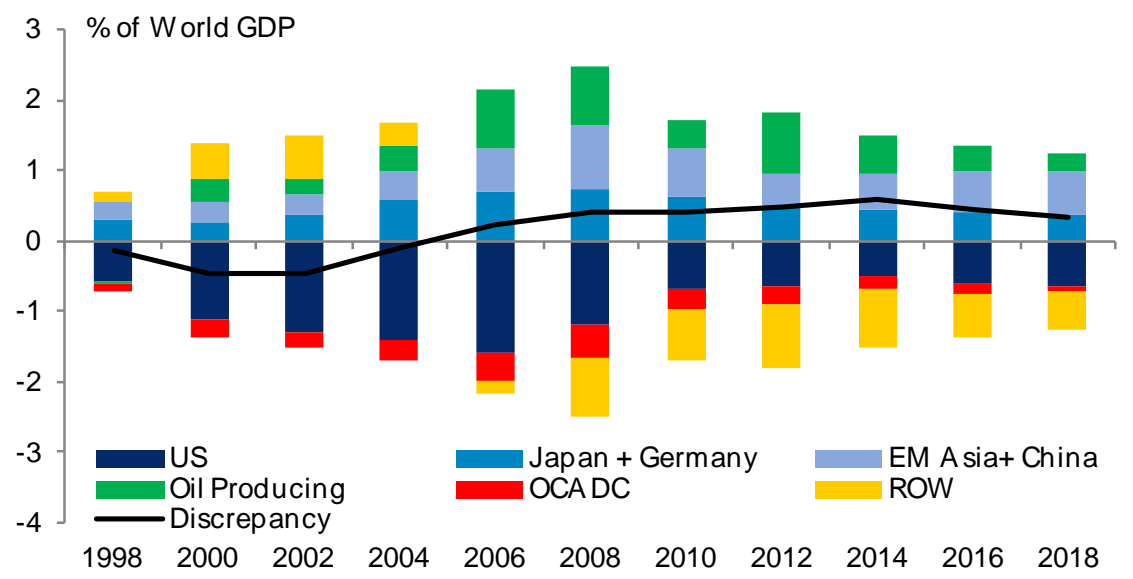

Source: IMF WEO Data,- April 2013, Deutsche Bank Research

Focusing on China and the United States, what could explain the apparent adjustment in the current account (or equivalently their savings/investment) imbalances? There is no doubt that the 2008 crisis generated very large changes in savings and investment behavior in both countries. In the US, the crisis generated a large shift away from private demand toward government demand as the fiscal deficit reached about $8 \%$ of GDP. In China, there was a large shift away from net exports toward 
government-impelled investment. US household wealth declined significantly. Indeed, these shocks were so powerful that we would have expected the pattern of current account imbalances to be overwhelmed by them, at least temporarily. Yet the Bretton Woods II pattern of current account surplus and deficit remained, albeit at a reduced size, informing us that despite the change in scale of imbalances, the forces behind this behavior have not changed in a fundamental way since before the crisis. Capital continued to "flow uphill" for years after 2008 and still does.

Figure 7: China: Nominal GDP in \$US Trillion

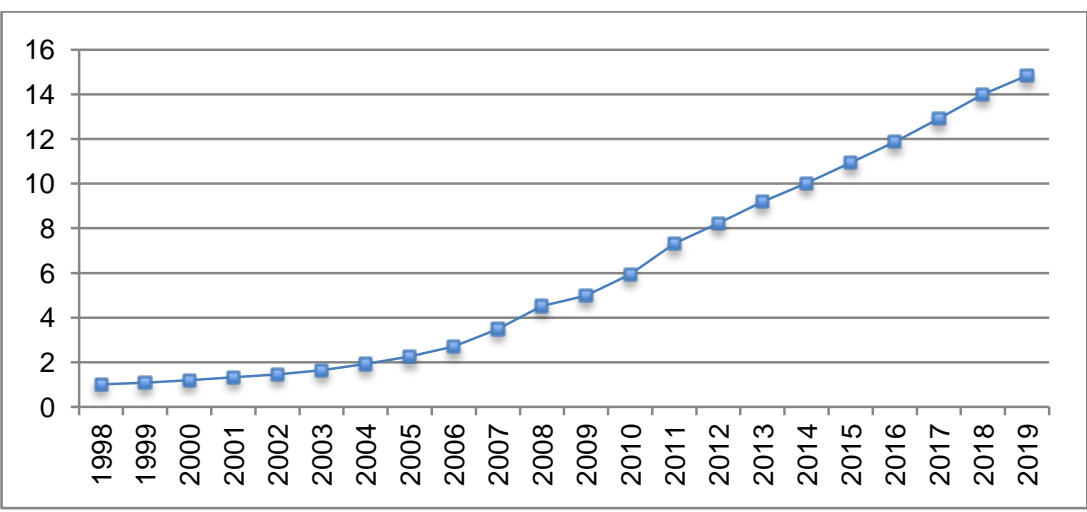

Source: IMF WEO Data, April 2014, Deutsche Bank Research

Moreover, the familiar practice of scaling these international flows to global GDP overstates the change in the system since 2008. In 2013, a Chinese current account surplus of $1 \%$ of GDP would have placed the same absolute dollar pressure on the industrial economies as would have a 5.6\% of GDP surplus in 2003. Western economies have hardly grown, while China's real GDP has grown more than 2.6 times in the decade. In dollar terms, it has grown 5.6 times, as indicated in Figure 7.

The absolute pressure of China's current account surplus on US and EU GDP and real interest rates is still greater than or equal to the pressure in every year of the decade except perhaps 2007 and 2008. Indeed, the dollar pressure from China's current account surplus in 2013 was 4.4 times greater than in 2003 and 2.7 times greater than in 2004. This was when we began circulating the Bretton Woods II idea and when others claimed these levels were unsustainable. If the IMF's projections of GDP and current account are realized, China's current account surplus in dollars in 2019 will exceed its 2008 peak, as in Figure 2.

\section{Gross Capital Flows: Foreign Direct Investment}

Because it drives rapid industrialization, direct investment from rich to poor countries is the key ingredient in gross capital flows. Figure 8 shows the dollar amount and percent of total world direct investment to China and EM Asia. It is clear that the gross capital flows barely lost stride with the 2008 recession. There was a small decline in 2009, but this was erased in only one year. In the FDI dimension of Bretton Woods II, we conclude that very little has changed during the last decade. 


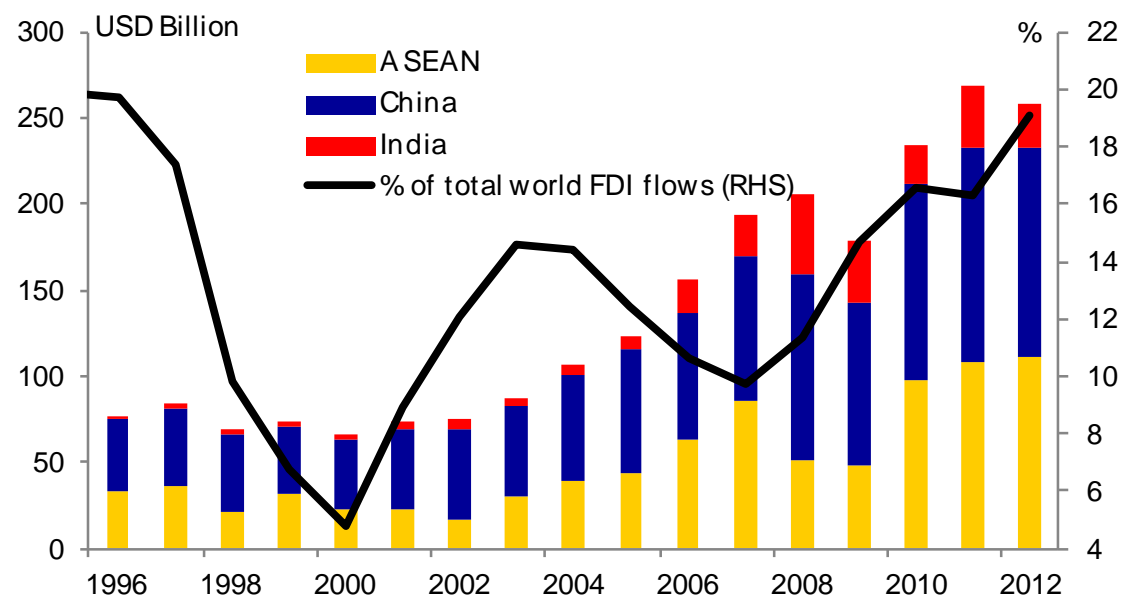

Source: UNCTAD, Deutsche Bank Research

\section{Unlimited Appetite for Foreign Exchange Reserves}

China's savings were exported via the accumulation of foreign exchange reserves and permitted and illicit private purchases of foreign financial assets. These flows were intermediated through the national balance sheets of the industrial countries, partly returning to China in the form of gross flows of FDI and partly remaining via the current account surplus. In effect, China's own savings financed the FDI flows into China.

China's foreign exchange reserves have continued to grow at a rapid rate as depicted in Figure 9, reaching USD 3.99 trillion at the end of June 2014. From January 2013 through June 2014 alone, China boosted its foreign exchange reserves by USD 681 billion. This increment itself was 1.7 times China's entire stock of foreign exchange reserves in 2003, when we first wrote on the system. As its central projection, the IMF expects China's reserves to exceed USD 6 trillion by 2018. So, yes, China's accumulation of reserves has been without limits to the present day-a ten-fold expansion since 2003 when China's reserves were already judged excessive.

Figure 9: China: Foreign Exchange Reserves, \$US Trillion

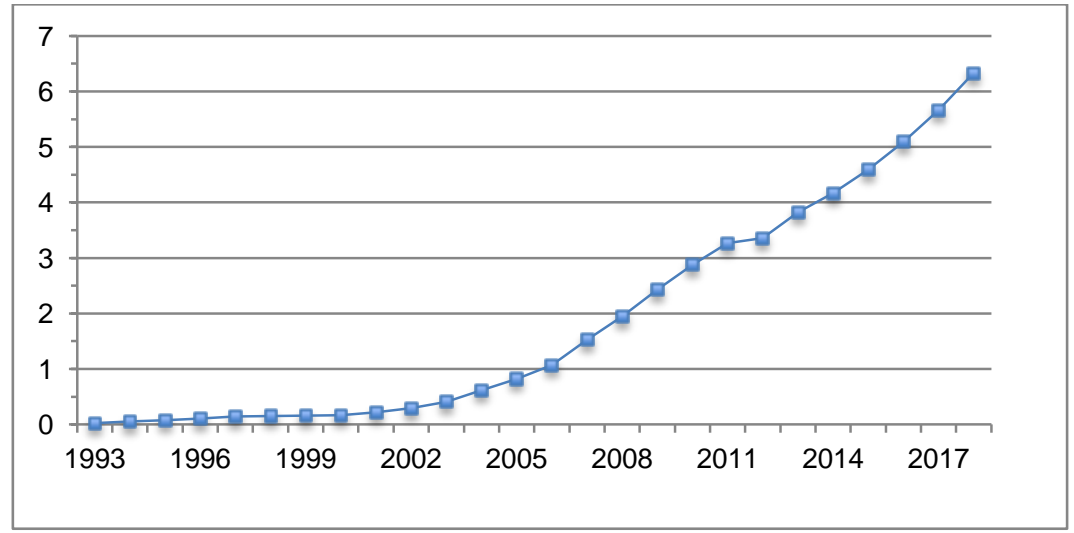

Source: IMF, Deutsche Bank Research 
When we promulgated the Revived Bretton Woods framework in 2003, China's reserves were about USD 300 billion. We said that the magnitude of reserves and exchange risks taken would be purely secondary considerations relative to the growth and employment objective. ${ }^{19}$ Rather, the development strategy was motivated entirely by the politics of employing the population in an environment of rising wages

As evidence of China's indifference to the risk/return aspects of its foreign exchange reserves, we can point to the cost of carry and losses from appreciation of the RMB relative to the USD and the euro. Interest rates for the USD part of China's foreign exchange reserve assets and interest rates paid by the Chinese government on shortterm local currency bonds are shown in Figure 10.

\section{Figure 10: US, China: One-Year Interest Rates}

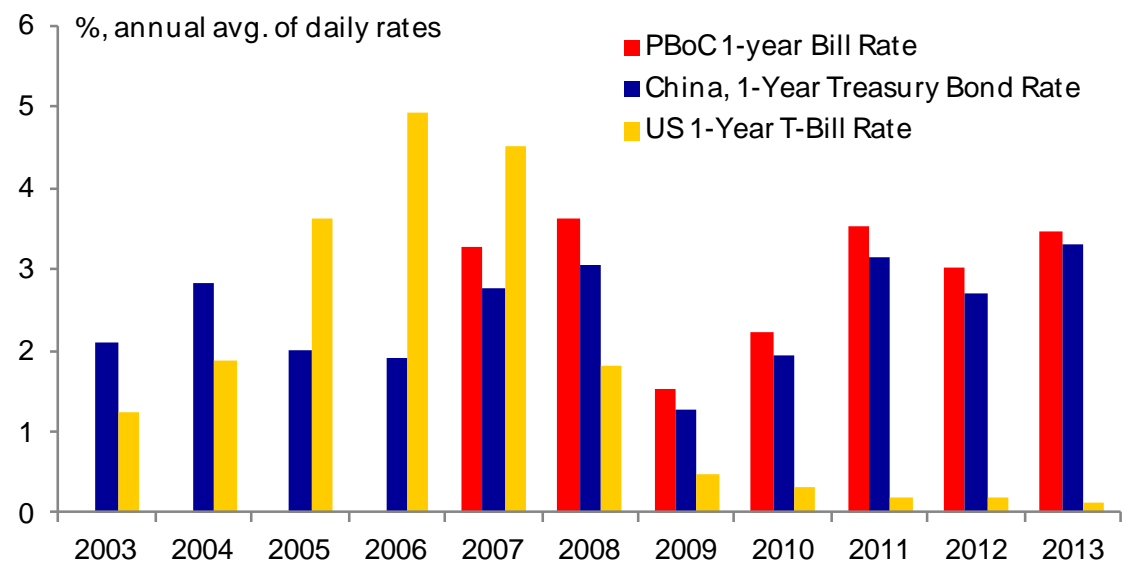

Source: CEIC, FRB, Deutsche Bank Research

In 2003, the RMB-USD exchange rate was fixed at 8.28 , and the carry was negative for the People's Bank of China (PBoC)-about $1 \%$ on US T-bills vs. $2 \%$ for one-year bonds in China. The PBoC would have run a 1\% loss in the 2003-4 pegged rate period, unless it held longer-term USD securities. By 2005, the carry had become positive, with the US T-bill rate at about 5\% and one-year bonds in China at 2\%. Therefore, from 2005 through 2008, China would not have generated much of a book loss on its foreign exchange reserves via the gradual appreciation of the RMB after the crawling peg began in July 2005 with a 3\% spike appreciation. With the collapse of US T-bill yields to near zero by 2009, the cost of carry to China rose to $3 \%$ by 2011 and has remained there to the present day. China immediately resumed a de facto hard peg to the dollar to reduce the pressure on its exports after the 2008-9 recession. After the crawling peg was reintroduced in 2010, the RMB appreciated by an average of 3.3\% per year through 2013, so China shouldered both the carry and appreciation losses, totaling above $6 \%$ per year. Even as it moved into longer-term USD securities, it still suffered a negative carry. ${ }^{20}$ Nevertheless, China nearly doubled its foreign reserve holdings in the five years after 2008. All this is prima facie evidence that the risk/return performance of China's foreign exchange holdings is not a serious consideration.

\section{Currency composition of reserves}

Figure 11 shows the currency composition of international reserve assets. This history is important because many experts predicted that the Bretton Woods II system would

19 This was markedly contrary to the generally accepted view in 2004-5 that the risks China was taking as it accumulated reserves would reach a limit and would be paramount in ending the system soon.

20 By June 2012, long-term debt and equity holdings amounted to almost the entirety of the USD 1.6 trillion of China's claims as accounted by the US Treasury. A standard assumption in the financial markets is that bonds held by SAFE have a seven-year average duration. 
end as peripheral country central banks hastily sold dollar reserves to avoid the credit and market risk associated with large claims on the United States. Clearly, there has been no change in the appetite for USD-denominated reserve assets. The currency composition of China's reserves is not public information but recent studies suggest that 60 to 70 percent are USD-denominated. ${ }^{21}$

Figure 11: Currency Composition of International Reserves

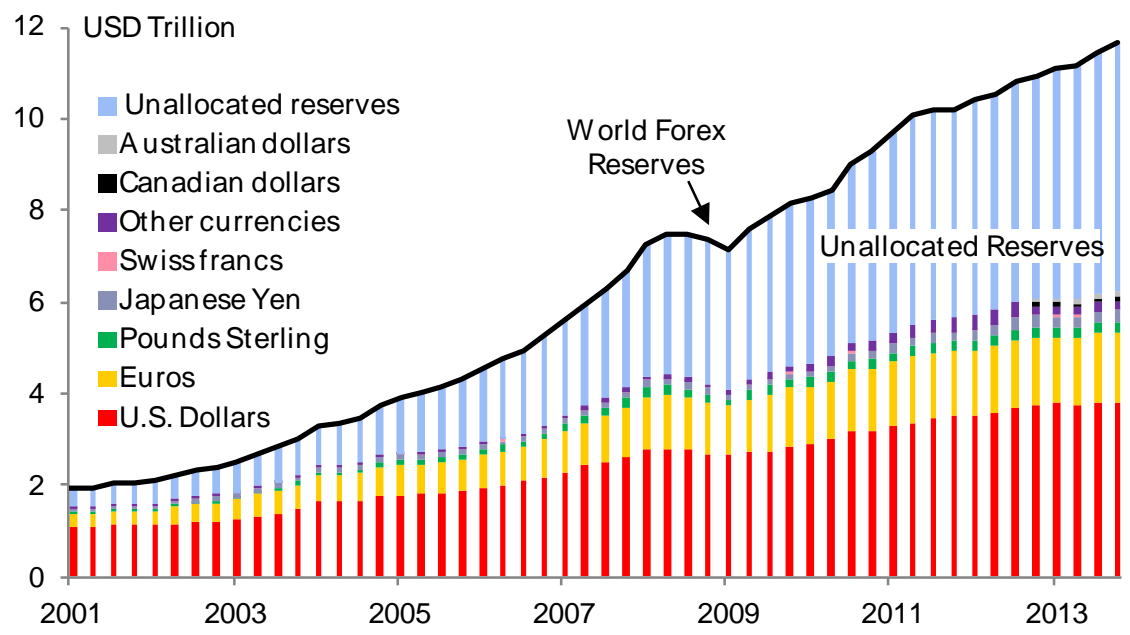

Source: IMF COFER, Deutsche Bank Research

Foreign exchange reserves are collateral to encourage FDI

Within the Bretton Woods II system, the role of net capital flows (current account imbalances) is to support the pattern of gross capital flows needed for China's growth strategy. Central to our framework is the idea that the remarkable explosion of twoway gross capital flows between rich and poor countries since 2000 was not causal to an increase in the demand for international reserves in emerging markets. On the contrary, the growth of reserve holdings associated with export-led growth provided de facto protection for foreign private investors in emerging markets and thereby caused the gross flows. The logic here is that private capital flows balanced in an accounting sense generate an imbalance in political risk between countries. As a result, balanced private capital flows are likely to be quite constrained in absolute magnitude because rich country gross private claims on residents of poor countries are not sufficient protection.

The only credible protection has been net goods already exported from the poor country. The powerful fact is that in a severe geopolitical clash rich countries can keep these goods by blocking repayment of their book debt to poor countries. The most likely vehicle for such action would be to freeze the assets of the poor country's government that are held in rich countries, in particular their international reserve assets. Our conclusion is that net foreign assets of poor countries support risk-taking by foreign investors. Thus, the observed pattern of current account imbalances was key to the success of the export-led growth strategy, especially for China. We were perhaps overly optimistic in expecting acceptance of this argument but continue to regard this as the most important analytical contribution of our Bretton Woods II papers.

Indeed, this innovation of gross FDI flows to China and larger still gross capital outflows from China was vital to the system because of the potentially problematic geopolitical relationship between a large, geopolitically unsatisfied, and ever more powerful China and its trading partners. The accumulated "uphill net capital flow"

${ }^{21}$ See Shi and Nie (2012) and Zhang, Wang, and Hua, (2010). 
serves de facto as up to a USD 4 trillion hostage in case of a geopolitical break, thereby making such a break less likely. It underpinned the willingness of foreign capital to commit to China. The net outflows were vital to get the gross FDI inflows moving. It was the supply side effects of the gross inflows that generated the industrial flowering. Thus, our theory intimately connected gross and net capital movements. ${ }^{22}$

This was the only way to get China's development model to work on the scale it has. The economic sanctions and threats to Japanese capital in China even in the minor disputes over the Senkaku/Diaoyu Islands underscore the vital role of current account surpluses in China's current development model. Similarly, conflicting claims among countries with coasts on the East and South China Seas signal the potential for geopolitical strife. Claims that the government of the United States would not threaten financial assets for political reasons have surely been put to rest by recent sanctions imposed by the US and European countries on Russian officials and are contradicted by the historical behavior of the US.

In 2004, we put together an illustrative "collateral table" for which we assumed a 50\% initial margin and $100 \%$ variation margin on FDI inflows to China. ${ }^{23}$ These collateral requirements were drawn from commercial rates for actively traded EM equities. We arbitrarily assumed a steady $10 \%$ annual capital gain on FDI to determine the variation margin required. With these assumptions China's reserves roughly matched the collateral a private entity would have required for the observed stock of foreign direct investment in China. We also extended this methodology to direct investment in all emerging markets and found similar results.

For this paper, we have updated the collateral-reserves relationship for new data, and we have also dropped the arbitrary assumption of a $10 \%$ annual capital gain for FDI. In this thought-experiment, we assume that the collateral theory is correct. Then we solve for the constant annual capital gain under which the implied collateral best matches the actual reserve accumulation. For each rate of capital gain, there is a path of implied collateral. We can then observe the percentage deviation of actual reserves from this implied amount. We searched over a range of possible rates of capital gain from 0.1 through 0.15 , and found the one that minimized the sum of squared deviations net of the mean deviation. The least squares minimizing rate is $13.7 \%$.

In Figure 12, we show the levels of reserves against implied collateral for 1993-2013. An average return of $13.7 \%$ does not seem unrealistic and is quite close to the arbitrary 10\% we used earlier. The residuals, positive from 2007 through 2011 and negative for other years, obviously do not suggest a random pattern. This may stem from the highly simplistic assumption of a constant rate of capital gain for the period. ${ }^{24}$

\footnotetext{
22 This is in contrast to the textbook model, which gets the net flows moving as a consumptionsmoothing phenomenon. Bolted on whole from theories of financial diversification, the gross flows are an afterthought that adds little to the growth story.

${ }^{23}$ Dooley, Folkerts-Landau, and Garber, NBER Working Paper 10727, 2004.

24 There is evidence that the rate of return to FDI in 2006 was 22\%. World Bank, 2006, p. 17.
} 
Figure 12: China: Collateral vs. Reserves

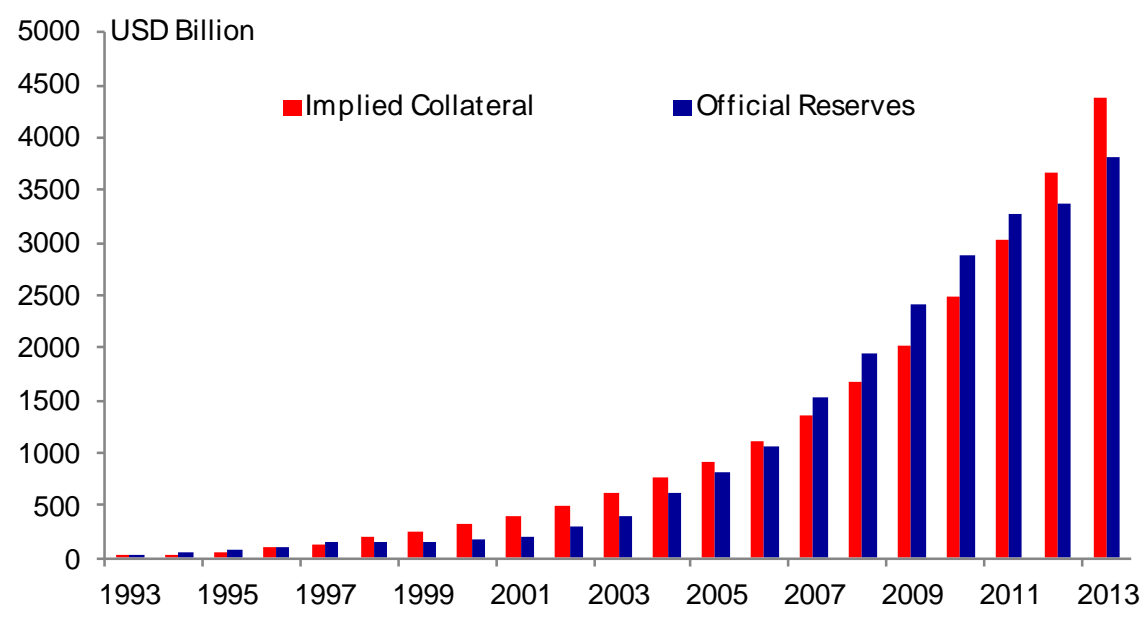

Source: CEIC, Deutsche Bank Research

\section{Inflation}

We predicted that inflation in China would be kept under control, in spite of the massive foreign exchange intervention. The authorities would use the usual forms of sterilization and financial repression-government or central bank bill sales pushed into banks and increases in the required reserve ratio. Although inflation has displayed a different pattern, it has not cumulatively been much greater from that in industrial countries since 2003, as indicated in Figure 13. It has evidently not been excessive enough to force a halt in the exchange market intervention. The required reserve ratio ranged between $6 \%$ from $1999-2003$ to $17.5 \%$ by 2008 . It then fell because of the global crisis to $15.5 \%$ in 2009 , rising again to $21.5 \%$ by 2011 , and falling to $20.5 \%$ by 2013 , as shown in Figure 14 . For the years 2003-2013, inflation in China, the euro zone, and the US averaged $3.02 \%, 2.01 \%$ and $2.31 \%$, respectively. Evidently, the Bretton Woods II system was not excessively inflationary for China.

Figure 13: CPI Inflation in China, US, and Euro Zone, \% yoy

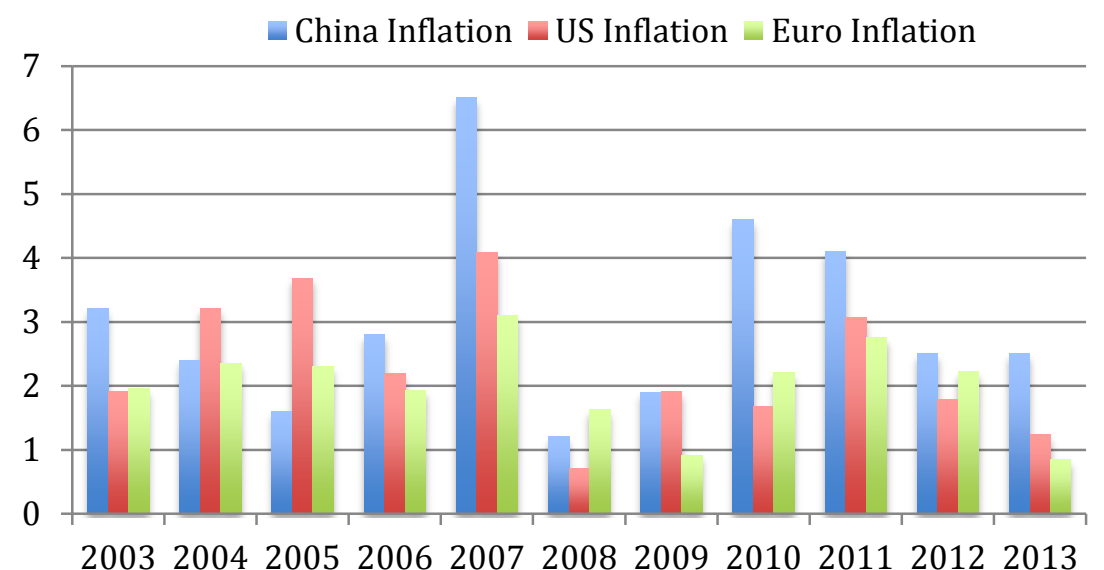

Source: IMF WEO, April 2014, Deutsche Bank Research 
Figure 14: China: Required Reserve Ratio

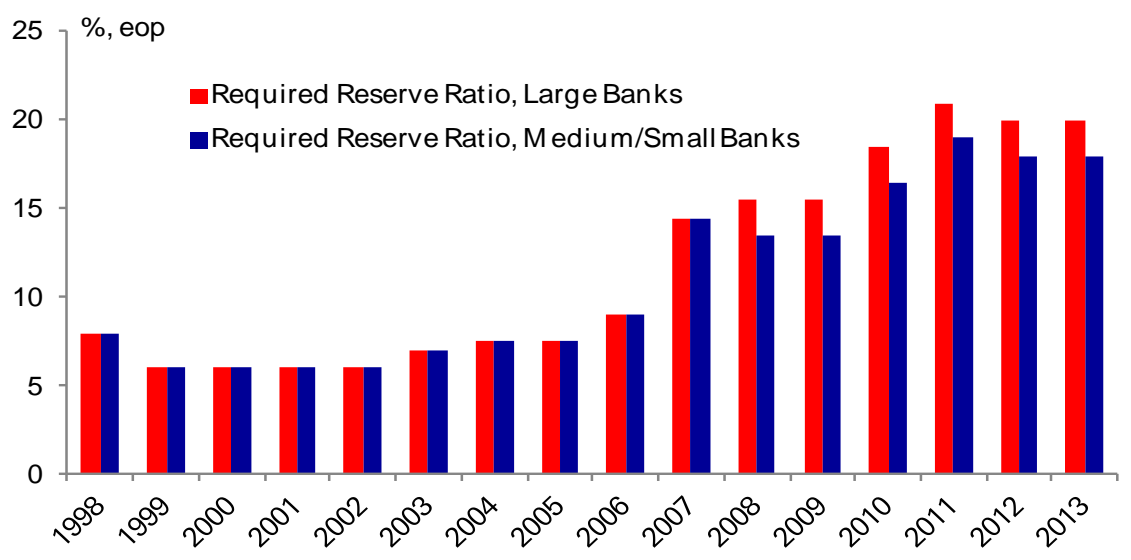

Source: CEIC, Deutsche Bank Research

Other EM countries would join the system and acquire large amounts of international reserves.

Figure 15 presents the explosive growth of EM country reserves across all regions from 1999 through 2013. This acquisition decelerated but still continued even after the 2008 crisis. Figure 16 indicates that many Asian economies have significantly increased their reserves since 2003. Malaysia and India had large, one-off declines due to capital outflows during the global crisis, but they both then rebuilt their reserves to or beyond their 2008 peaks. Since 2012, these reserve accumulations have halted.

Figure 15: Emerging Market International Reserves

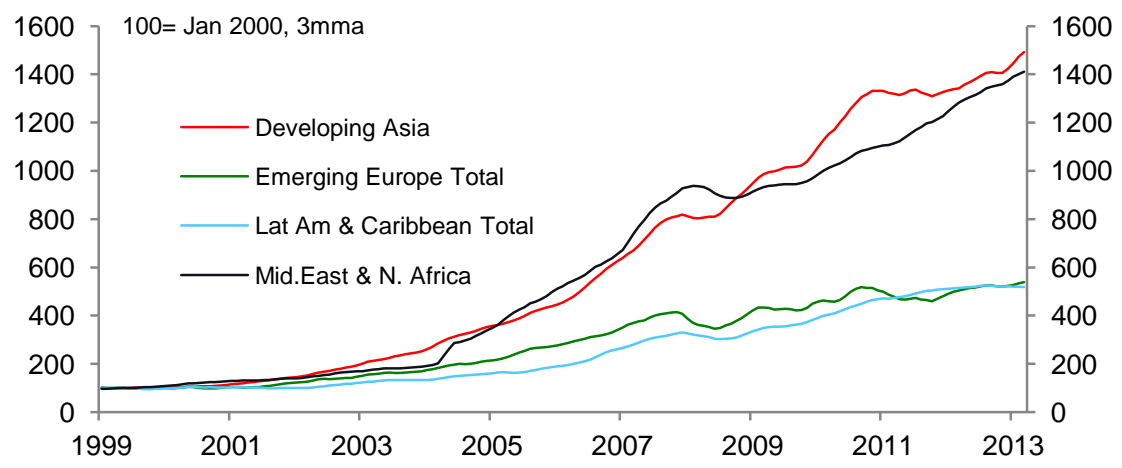


Figure 16: Other Asia Reserves

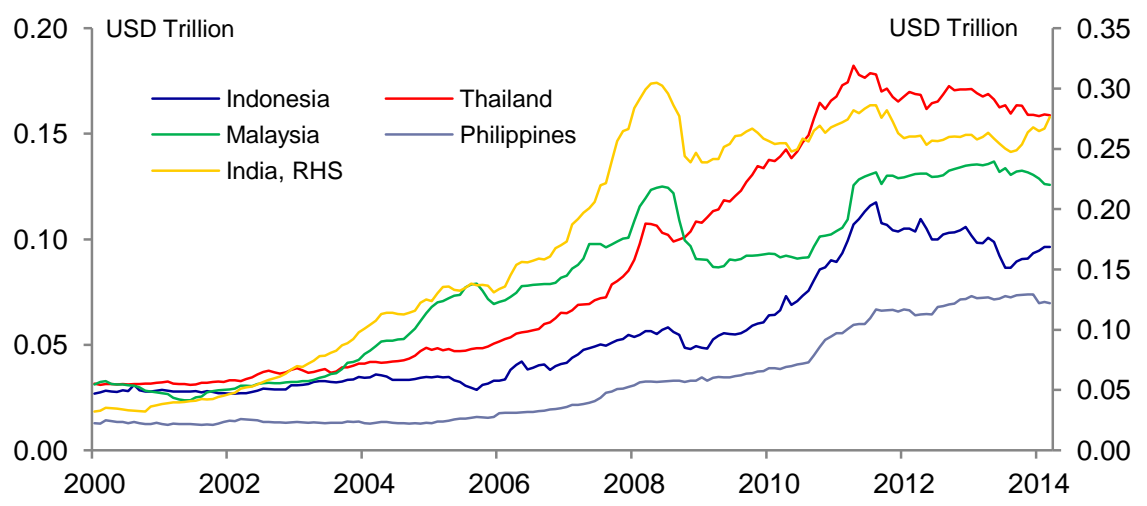

Source: IMF IFS, April 2014, Deutsche Bank Research

\section{Global Real Interest Rates}

We claimed in 2003 that the system's China phase would last 10 or more years because of the congruent interests of China and the US. This meant that China would maintain its rapid growth and would be a capital exporter on a macroeconomic scale. Also, unlike other, smaller East Asian countries that had used this strategy, it would be a driver of global prices, especially the global real interest rate. Therefore, the longterm real rate in the US would be falling and would stay unusually low in all phases of the business cycle. This applied as well to the rest of the industrial world, whose financial markets were closely integrated with the US.

Figure 17: Long-Term Real Interest Rates: 10-Year Tips; 10-Year OAT Euro I

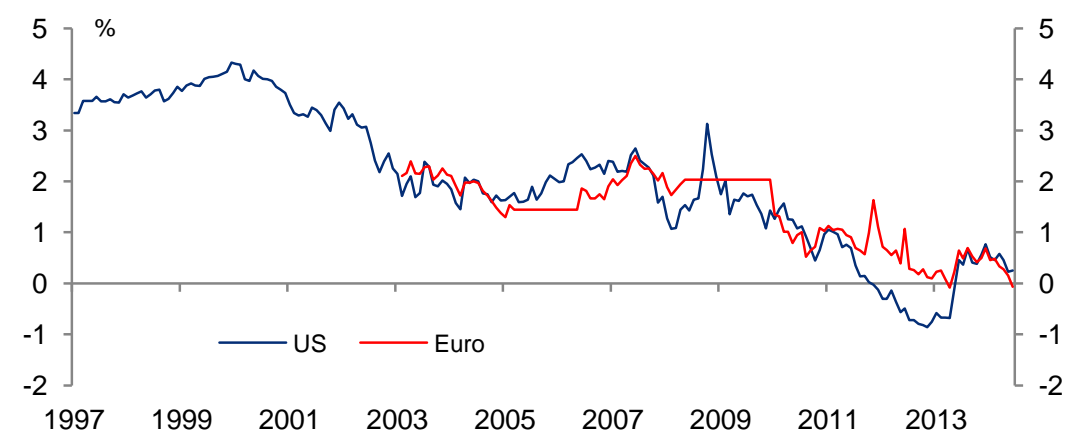

Source: Bloomberg Finance LP, Deutsche Bank Research

In a non-inflationary environment, the US 10-year Tips rate has fallen from a "normal" rate of about 4\% approaching the peak of the US growth phase at the end of the 1990s to a record low of $-0.5 \%$ in another supposed growth phase before rising back to about 0.7 in March, 2014. Remarkably, it had declined to and stayed at a low level during the worldwide boom through 2007, in spite of an inverted US yield curve that lasted a record amount of time-the Greenspan conundrum. Then the real rate continued to fall after the 2008 crisis and recession, reaching the modern record low. French OAT Euro I rates followed an almost identical pattern at nearly identical levels, underscoring the close integration of US and EU financial markets. 
The overall pattern for nominal 10-year Treasuries is similar, and the low ex-post real returns have emphatically not been due to surprise inflation during the last decade, unlike in previous episodes.

Looking forward, the long-term real interest rate on Treasuries will probably rise somewhat as the Fed's QE3 manipulation finally ends. With US growth returning to a normal secular level and the end of the Fed's taper, the real rate should nevertheless continue to stay below what we used to regard as a norm as long as the pattern of net capital flows continues. The depressing effect on real interest rates in the United States and other markets integrated with the US will depend on the scale of these capital inflows.

\section{Industrial and Peripheral Country Exchange Rates.}

No US exchange rate crisis when the system ends.

In the past decade, there has been no US exchange rate crisis; nor has the real interest rate (including Treasuries) spiked other than briefly during the Lehman crisis. ${ }^{25}$ However, the jury remains out on this forecast, because the system has not yet ended.

The euro would first appreciate against the USD; then both the euro and USD would depreciate together vs, the RMB.

In our initial 2003 paper, we said that the euro, then at parity with the dollar, would appreciate because of the burgeoning US current account deficits. By 2005, after the PBoC began its managed appreciation of the RMB against the USD, we concluded that the euro had appreciated against the dollar in the previous few years to reflect the financial market's learning of how the system worked. From 2005, onward, therefore, we said that the euro and the USD would move together against the managed appreciation of the RMB, except for asynchronous business cycles. From Figure 18, it is evident that euro-dollar has traded in a range between approximately 1.2 and 1.6 for the last ten years. Therefore, the secular appreciation of the renminbi against both currencies has been approximately uniform.

One lasting effect of the 2008 crisis and the subsequent euro crisis is the inability of peripheral countries in the euro zone to borrow. Together with Germany's surplus, this implies that the euro zone will become a net current account surplus region, as has already happened, a result that will tend to keep the euro at the stronger side of its range against the USD.

\footnotetext{
25 Securitized fixed income products did collapse with the housing market, but there was no collapse in credit to the US, Inc.
} 
Figure 18: Euro-USD Exchange Rate

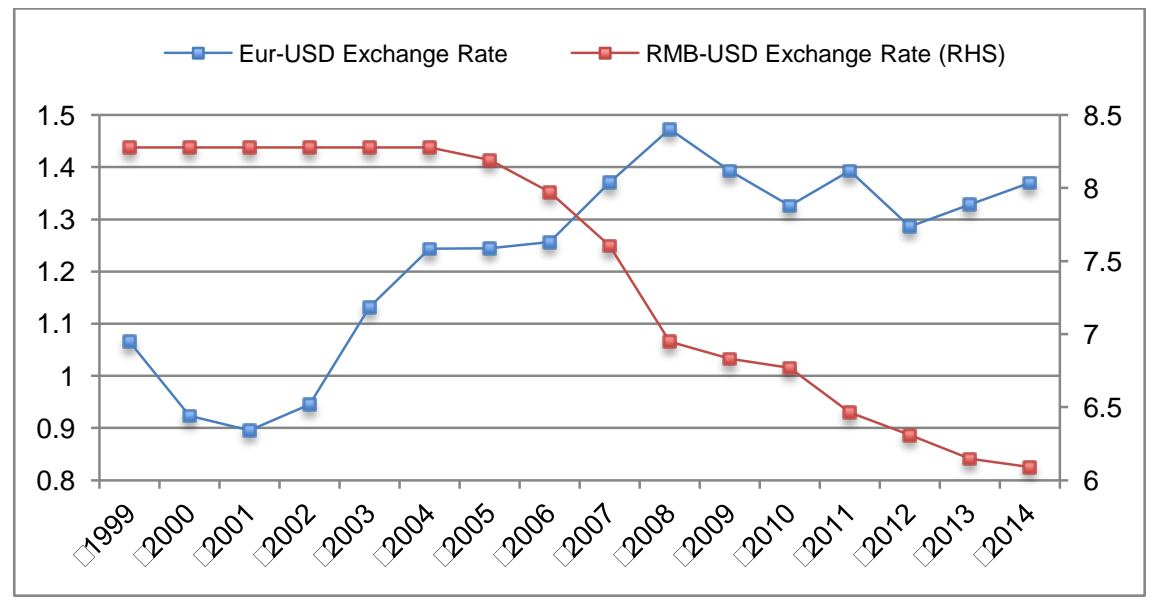

Source: FRB, Deutsche Bank Research

This dollar-euro stability was contrary to some academics' predictions that all currencies would appreciate massively against the over-indebted, profligate US. Specifically, the key feature of the exchange rate history is that there was no general flight from the dollar during the 2008 crisis.

Japan would intervene in the exchange market again.

In 2005, we predicted that if the yen appreciated enough, Japan would intervene massively again, as in 2003-2004. The Ministry of Finance ultimately did intervene but only after a hiatus of more than six years. Japan had been intervening by selling large amounts of yen since 1995, but 2003 brought progressively more massive interventions designed to beat back one-way speculation. The trigger point for intervention in 2003 seemed to be at a real effective exchange rate of about 103 . Seemingly ineffective, the size of the intervention reached its peak in the first quarter of 2004 and then ceased, although the real effective exchange rate had appreciated to 106. By then, Japan had become by far the largest global holder of foreign exchange reserves. However, the yen's real effective exchange rate then steadily depreciated to 82 just before the Lehman crisis in September 2008. It then rapidly appreciated, again reaching 103 in August 2010, driving the MoF to intervene in September 2010. By November 2011 , the MoF had sold $¥ 16.4$ trillion to buy around USD 210 billion, but the yen's real effective exchange rate then crept up above 100 until Abenomics began at the end of 2012. Since then, the Bank of Japan has intervened in the bond market with the express intention of generating a weaker yen but has not yet intervened in the foreign exchange market. 


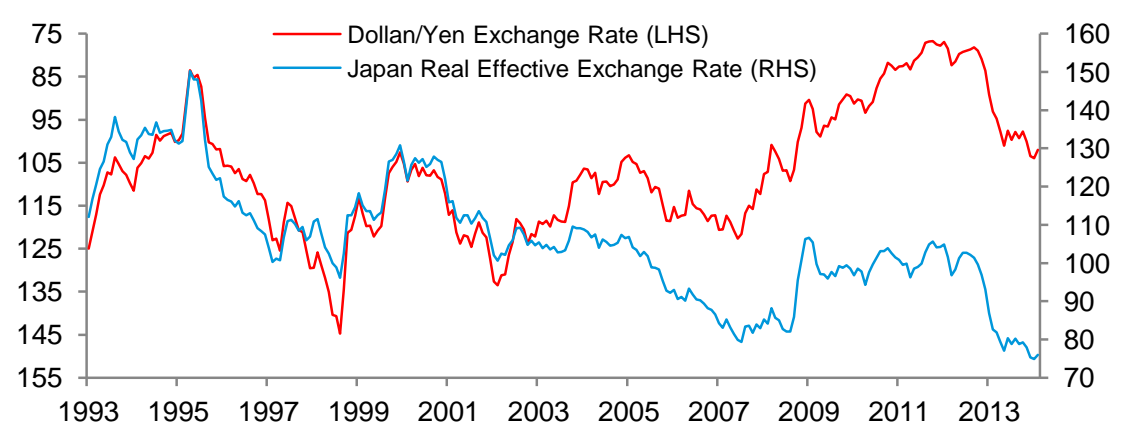

Source: Bank of Japan, Deutsche Bank Research

The euro zone might have to join the system and undervalue its currency to protect its labor force from too much of a dislocation.

It is evident that the euro zone did not manipulate the euro exchange rate. However, it is now a truism that Germany gained from its membership, and indeed control of monetary policy in the euro zone, because overall ECB policy effectively kept the exchange rate undervalued for Germany, given its labor market reforms. The issue of its exports' being priced out of global markets did not arise for Germany-indeed, the sorts of industrial goods that a growing China needed were exactly Germany's specialty. For most of the euro zone, this was not the case. It is also a truism that ECB monetary policy led to an overvalued currency for the southern European members and the hollowing out of their export and tradable sectors in the face of imports from China. We did not reckon on the overwhelming German control over ECB policy, which prevented the sort of action to promote depreciation that almost any country in Europe previously would have undertaken to prevent depression. Occasionally, there are ECB rumblings about the high euro exchange rate, but only in the context of a possible shift to unconventional monetary policy, not an exchange market intervention.

\section{Labor Market Supply Effects in China, the US, and Other Industrial Countries}

The US would not protect its industrial workers; US revealed preference is for continuing the Bretton Woods II system.

Claims that the Bretton Woods II system has harmed the US rather than being mutually beneficial are understandable, given the obvious dislocation in the US manufacturing labor force. In 2004, we took the position that the US benefited simply on the basis of the revealed preference of the US Administration and Congress. The Treasury annually has had the opportunity to declare China a "currency manipulator" and thereby trigger protectionist action, and the Congress could have passed further legislation. Various Administrations and Congresses have grumbled for public consumption about currency manipulation but done nothing about it. In the last fifteen years, the US has moved from a center-left Administration to a center right Administration and then to a progressive Administration, but none has imposed serious protectionist action. Although the system clearly harmed labor in the manufacturing sector and benefited capital, the evidence from the last decade reveals even more strongly that no action will be taken against the system. Revealed preference indicates that those calling the shots in the US have benefited and continue to benefit. Far from blocking cheap merchandise imports, even the party that traditionally carried the banner of manufacturing labor has instead taken up capital's traditional position and fostered the importation of cheap labor.

Europe would protect its industrial workers.

Europe certainly did not act to protect its industrial workers, as we partly explained in our industrial country exchange rate discussion above. We have been surprised that 
the euro zone countries would accept such high rates of unemployment for so long. But just as capital was politically in control in the US on the issue of imports from China, so it was also evidently in control in Europe via conservative monetary and fiscal policy. When we said "Europe could not absorb this flood of goods, given its structural problems and in the face of absorbing Eastern Europe as well," we did not imagine that the authorities in the euro zone could bear protracted unemployment levels above $25 \%$ in major southern European countries. ${ }^{26}$

\section{Absorption of labor and the real wage in China.}

The absorption of rural labor in industry, infrastructure construction, and services has clearly been associated with rising real wages. For many years, real wage growth exceeded 10\% annually, as in Figure 20. In US dollar terms, wages have more than tripled since 2001 but are still well below levels in the United States and other industrial countries. Unit labor costs have also risen as real wages have outstripped productivity gains. ${ }^{27}$ In some industries China is now just competitive with other emerging markets. However, Figure 4 indicates that this has not yet affected China's aggregate export performance. China's share of world manufacturing exports has risen as much during the past last five years as it did during 2003-2008.

Figure 20: China: Real Wage Growth

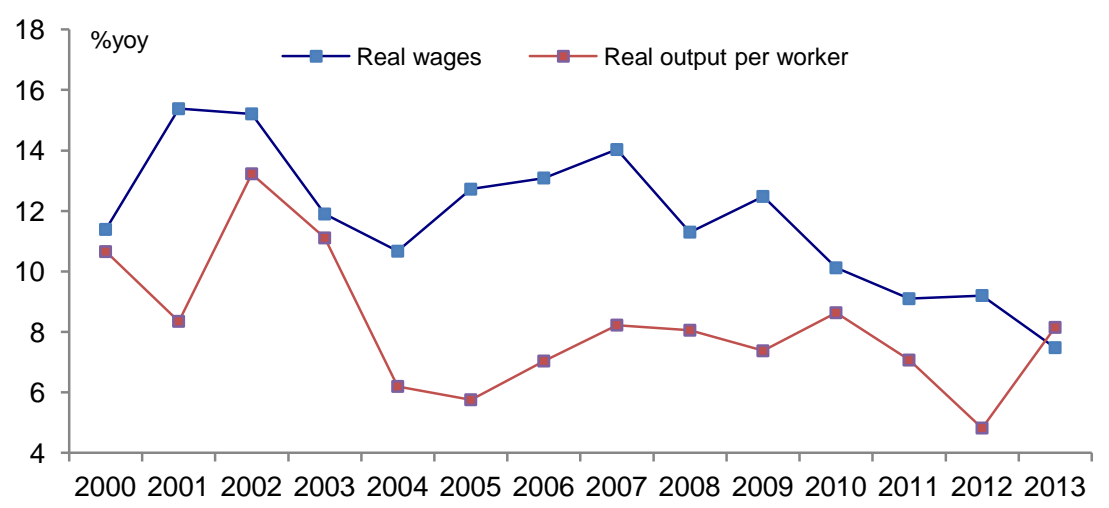

Source: CEIC, Deutsche Bank Research

\section{$\mathrm{V}$. India as the new driving force of the periphery?}

In 2003, we thought that India could follow or overlap China as the next major peripheral country in the Revived Bretton Woods system. It had a population of about 1.1 billion (currently 1.25 billion), 50\% younger than 25 years, and GDP per capita of $\$ 572.28$ India was comparable to China as a huge pool of low wage labor that industrial economies would also require decades to absorb. It has long been a classic twin-deficits country, so it would take a serious policy reversal to run China's level of surpluses. However, from 2002-2007, India appeared to mimic China's development pattern in several dimensions. This incipient "India phase" was a major aspect of the system's dynamics derailed by the 2008 crisis. Nevertheless, the election manifesto of the new Modi government in effect is a plan for an export-led development strategy.

26 "An Essay on the Revived Bretton Woods System", 2003, p. 23 in Asia, Interest Rates and the Dollar.

27 See Das and N'Diaye, p. 160, in Singh, Nabar and N'Diaye, eds., 2013.

${ }^{28}$ It is now at about \$1500, which was China's per capita income in 2004. 
Pre-2008 Crisis

India implemented some the same key policies that China used in its export-driven strategy, and many pre-crisis outcomes were comparable:

Controls and exchange rate pegging.

With effective capital controls, India kept its exchange rate tightly range-bound between 44 and 48 rupee/USD through 2007, as in Figure 21. The real effective exchange rate was similarly range-bound.

Figure 21: India Exchange Rate: Rupee/USD

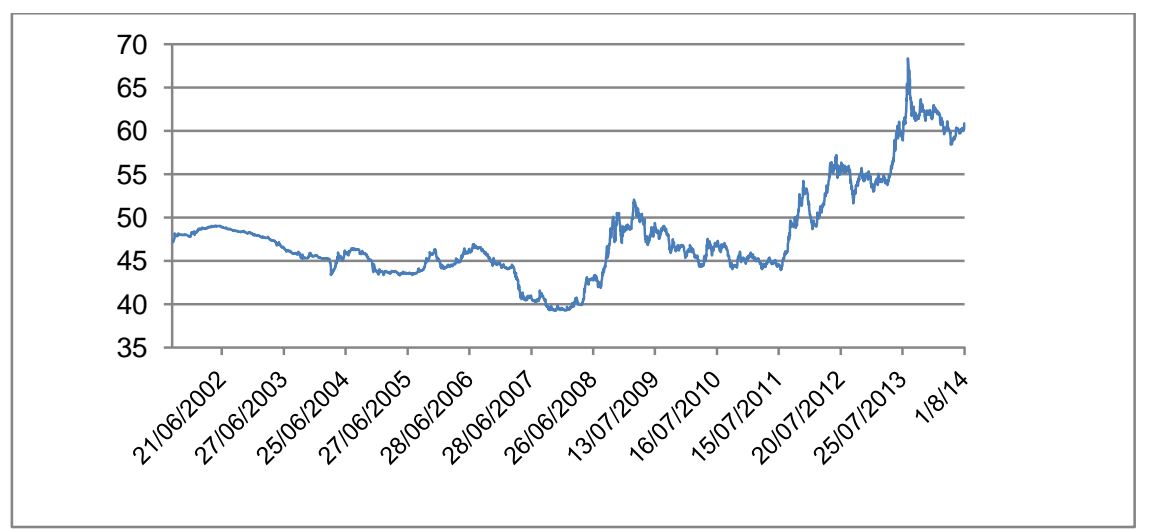

Source: RBI, Deutsche Bank Research

\section{Exchange market intervention.}

This was a period when India intervened intensely in exchange markets, with reserves rising from USD45 billion in January 2002 to USD302 billion in June 2008, as shown in Figure 16. As a ratio to cumulative GDP from 2002 through 2007, India's total foreign exchange intervention was $5.1 \%$ while China's was $11.8 \%$. Since China's foreign exchange intervention has been regarded as extraordinary, India's qualifies as also remarkable, even at half of China's ratio.

\section{No net capital imports.}

In spite of being a poor country to which capital should have flowed downhill in the textbook manner, India's current account/GDP ratio averaged around zero from 20022007. ${ }^{29}$ However, unlike China, India did not become a net exporter of capital except between 2001 and 2003.

${ }^{29}$ In dollars, the total deficit in this period was USD17 billion, .3\% of cumulated GDP. 
Figure 23: India: Current Account/GDP, \%

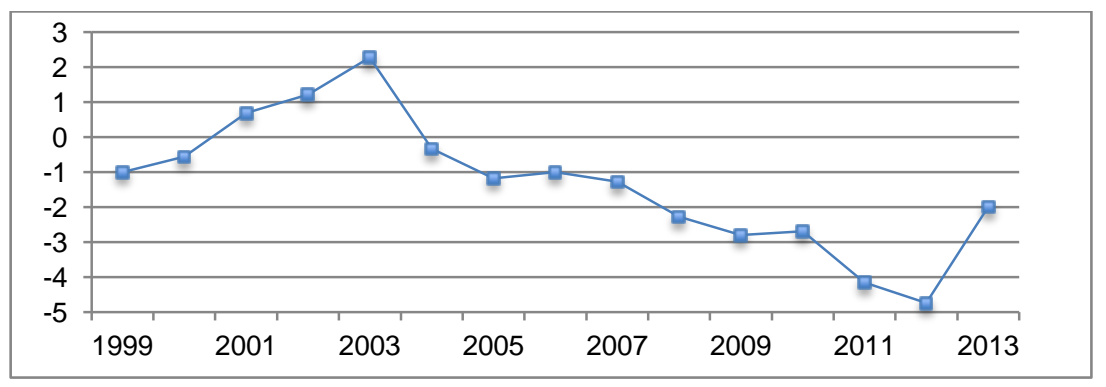

Source: IMF WEO Data, April 2014, Deutsche Bank Research

\section{Inward FDI.}

Granting foreign capital the rent from direct access to its low wage labor was a key element in China's strategy. From 1993 through 2005, India received only USD43 billion in FDI while China received USD602 billion, a 14/1 ratio. Then, from 2006 to 2012, India also effectively implemented this policy: FDI into China and India totaled USD718 billion and USD215 billion, respectively, a ratio of 3.3/1. As a ratio to cumulated GDP for the period 2006-2012, India's FDI imports were 2.2\%, while China's were $1.7 \%$.

\section{Figure 24: India: Inward FDI, USD Billion}

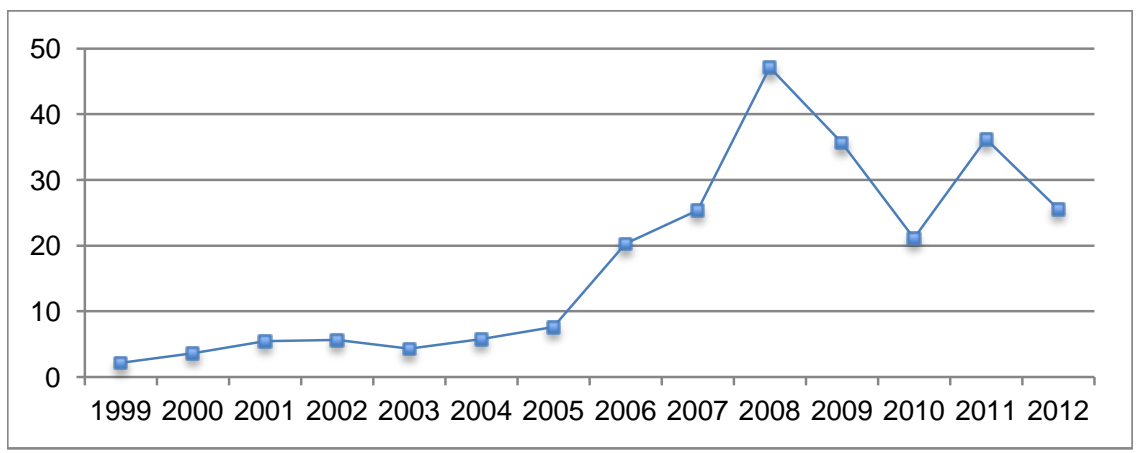

Source: UNCTAD, Deutsche Bank Research

Unlike in China, very little FDI went into manufacturing. Figure 25 shows the top ten sectors that attracted the inflows from 2000-2013.30 FDI did not start taking off until 2005 , perhaps reflective of the boom in outsourcing in that decade, which also shows up in the service trade growth surge in Figure 26 below. Almost 50\% of this FDI originated from Singapore and Mauritius (37\%) addresses. Japan, the US, the UK, the Netherlands, Germany, and France accounted for 33\%. 
Figure 25: India: Inward FDI, by Sector, 2000-2013

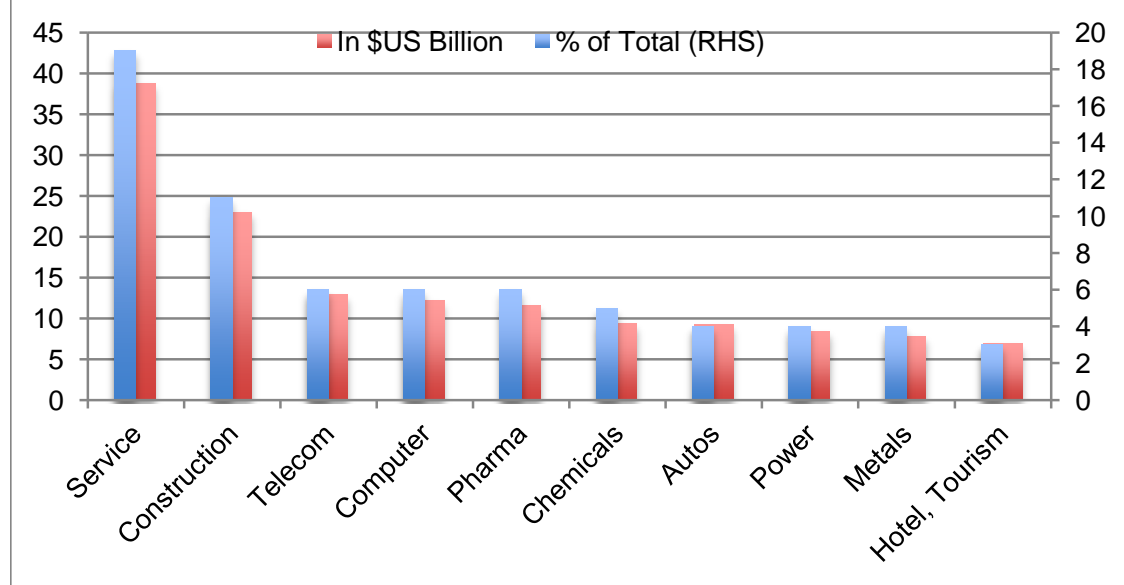

Source: DIPP , Deutsche Bank Research

Reserve accumulation financed FDI, not current account surpluses.

Official reserves increased by USD148 billion between 2004 and end-2008. In the same period, FDI totaled USD106 billion. Official reserve growth more than covered the FDI inflow as India's intervention pushed the inflows back out to defend against an appreciation of the rupee. In effect, the rest of the world's balance sheet was intermediating between official sector Indian savings outflows and foreign equity inflows, just as in China.

Export growth rates were comparable to China's.

Figure 26 displays export growth rates in India and China for goods and services. For goods alone, export growth in China generally exceeded that in India, which itself was impressively high through 2007. For exports of goods and services together, however, the two countries had very similar growth rates. This resulted because China's trade was almost entirely in merchandise, while India's included a large service element. With a large English-speaking, technically educated population, India was well placed to ride the outsourcing wave. This made white-collar jobs in the technical and clerical fields tradable goods, now in direct competition with this class of industrial country workers. 
Figure 26: India, China: Export Growth, Goods and Services, \% Change

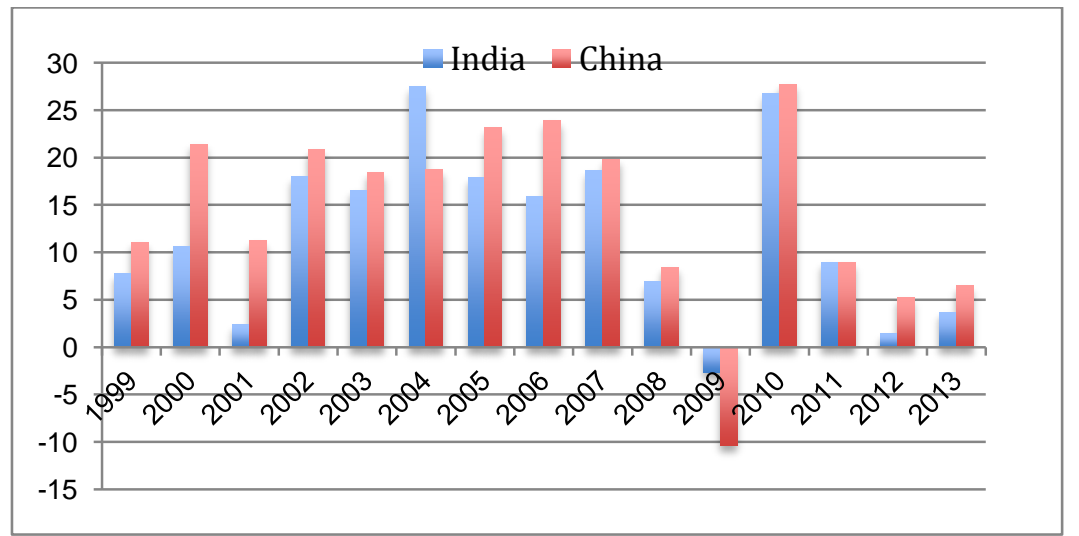

Source: IMF WEO 2014, Deutsche Bank Research

GDP growth.

The pre-crisis development policies added up to an impressive GDP growth. Starting from a much lower base than China's, India's GDP growth was comparable, averaging $8.8 \%$ and $11.7 \%$ per year from 2003-2007, respectively, for India and China. Figure 27 displays the level of GDP both in current and constant prices. ${ }^{31}$

Figure 27: India: GDP

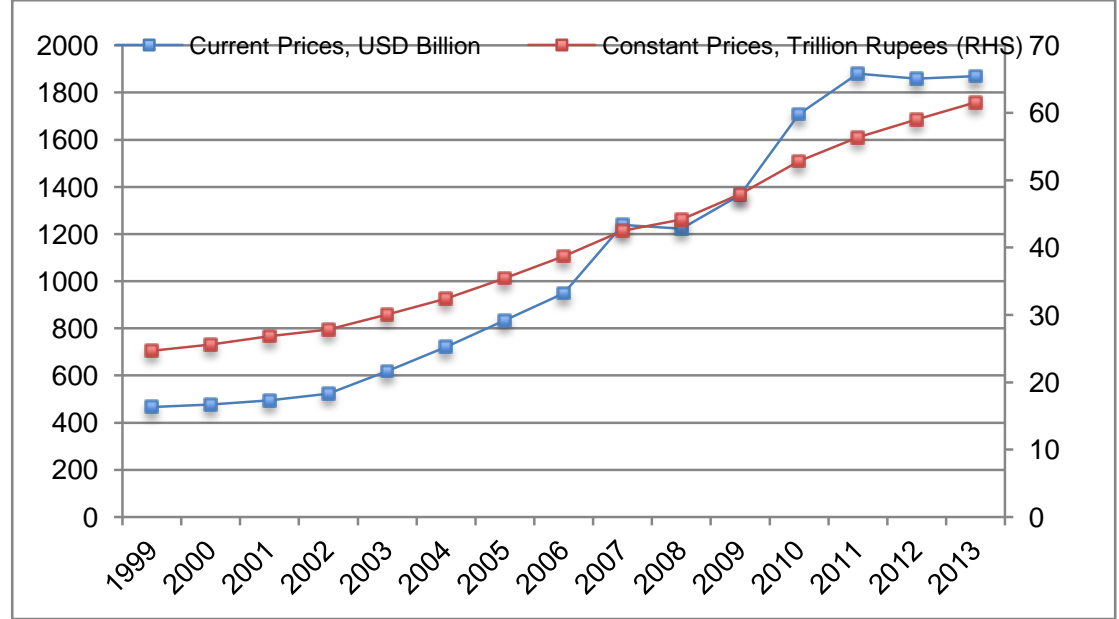

Source: IMF WEO Data, April 2014, Deutsche Bank Research

\section{Post-2008 Crisis}

Since the 2008 crisis, several key features of the export-driven growth strategy have ended or sputtered, while some have remained.

GDP growth fell.

Real GDP growth rates have remained positive, even recovering entirely in 2010; but the growth rate fell to an average 5.2\% from 2011-2013 a little more than half of precrisis levels. While, at an average of $8.2 \%$, China's growth rates have also fallen as industrial economies remain stagnant, China is much closer to the end of the strategy as its excess labor pool has diminished.

31 GDP in \$US flattened from 2011-2013 because of the depreciation of the rupee in this period. 
Current account in deficit.

India has become a net importer of capital, with a current account to GDP ratio averaging $-3.27 \%$ since 2009, as in Figure 23. Evidently, India ceased avoiding net capital imports in the last five years.

\section{FDI unchanged.}

FDI Unchanged. Inward FDI, while below the 2008 peak, has continued at the precrisis rate.

\section{Foreign exchange reserves.}

The rapid accumulation of foreign exchange ended, with reserves only now approaching their 2008 peak. This is in stark contrast to China, which has almost doubled its already massive reserves since the crisis. Even the USD118 billion of FDI inflows from 2009-2012 were not enough to offset the USD250 billion current account deficit for the period.

\section{Rupee depreciation.}

The Rupee/USD exchange rate re-entered its pre-crisis range of 45-50 immediately after the crisis and through mid-2011, but it has now rapidly depreciated to about 60 . The REER has also depreciated by about $10 \%$ from its pre-crisis range, consistent with the increased pressures from the deficit in standard theory.

\section{Export growth fell.}

After a remarkable recovery in 2010, export growth has fallen dramatically to average under 5\% per year during the last three years. Exactly paralleling China's experience, as in Figure 24, this has resulted from the stagnation in the industrial economies.

\section{The Outlook: Modi's Export Growth Manifesto}

Recent developments outline above suggest that India is not now on the path to replace China in the system But looking forward the Modi governmetn's plan, if implemented, would reload India into the periphery of a BW II system. The 2014 election manifesto of the Bharatiya Janata Party announced several economic goals. A country intending to push an export-driven development policy could hardly describe its policies and goals differently. In sum, the manifesto seems aimed at implementing the strategy even more vigorously. The manifesto espouses: "A strong manufacturing sector will...create millions of jobs and increase incomes for the working class. Above all, it will increase the revenue for the government and lead to import substitution to bring down the import bill. We will make India a hub for cost-competitive labourintensive mass manufacturing. (p. 29)."

Specifically, the manifesto proposes several policy goals to boost labor-intensive manufacturing. The current account deficit is to be reduced aggressively by focusing on exports and reducing the dependency on imports (italics ours). A program for ports, roads and rail to the interior, and airports is intended to facilitate international merchandise trade by eliminating severe infrastructural barriers. It also intends to eliminate the artificial bureaucratic barriers to commerce. FDI will be allowed in most sectors, except retail, and investment and industrial regions are to be set up as international manufacturing hubs.

Of course, a political party's manifesto is a wish list. Full implementation always collides with resource and political constraints. But taking it at face value means that India is readying itself to take up China's role as the next large periphery in the Revived Bretton Woods system. As we said in Section IV, the key to managing the export-driven strategy at a global macroeconomic scale is the enlistment of FDI. The extent of collateral limits FDI, but a large and persistent current account surplus relaxes the limit. In India, the government is now opening the doors to more FDI; and simultaneously, it intends to reduce the current account deficit. Our caveat is that it cannot expect a China-like attraction of FDI unless it can swing the current account 
into surplus. The manifesto seems to aim at these targets, but this is a case of wait and see for this next test of the collateral hypothesis.

\title{
VI. Conclusion: The End of the China Phase vs. the End of the System
}

We have been careful throughout this paper to use the term "China phase" of the system. We view the Revived Bretton Woods system as a continuation of the global monetary system that originated in the immediate post-war period. It emerged to solve the problem of reintegrating a periphery's large, capital-poor labor force into the global industrial economy. That system has remained either active or dormant in the background for nearly seventy years. It is currently active, with China as the peripheral country that is moving rapidly toward the center. In this sense, the "China phase" can end, while the system continues, prepared to activate itself as the next peripheral country or region emerges.

Our views on the constancy of the system have not changed since 2003:

\begin{abstract}
We used to have a view that 1) there was a system (Bretton Woods) that evaporated thirty years ago into no system at all and 2) now a semi-system has emerged anew. But, in fact, the system has been the same throughout, just manifesting itself in different forms because the original emerging markets (Europe and Japan) developed and did not need the center's intermediation any more. There was no one to replace these countries for two decades. But with the collapse of socialism came a new litter of emerging markets, and the background system that is the incubator of such economies has reanimated itself. 2003, Essay, p. 24.
\end{abstract}

The 2008 financial crisis was the end neither of the international financial system known as Bretton Woods II nor even of its China phase. But the China phase is programmed to end within a few years. This means that China will join the center with the US and the EU. The old industrial center has seen its manufacturing and white collar clerical labor force displaced, and one might think that it cannot withstand yet another cheap labor giant like India also pushing in. But now that China will be in the center, the center's capacity for absorption of another massive labor force will be a multiple larger. The test of the survival of the overarching system will be if China also stands willing to tolerate a cheap labor competitor. Or will an additional 1.4 billion population finally force the system to close out the periphery? 


\section{References}

Bayoumi, Tamim and Franziska Ohnsorge, "Do Inflows or Outflows Dominate? Global Implications of Capital Account Liberalization in China," IMF WP/13/189, August 2013.

Bharatiya Janata Party, Election Manifesto 2014.

http://bjpelectionmanifesto.com/pdf/manifesto2014.pdf

Dooley, Michael, David Folkerts-Landau and Peter Garber, (June 18, 2003) "Dollars and Deficits: Where Do We Go From Here?" Deutsche Bank Global Markets Research.

"An Essay on the Revived Bretton Woods System," Deutschebank Global Markets Research, September 2003. NBER Working Paper 9971.

(February 2004a) "The Cosmic Risk: An Essay on Global Imbalances and Treasuries" Deutschebank Global Markets Research, (February). Also in "The Revived Bretton Woods System: The Effects of Periphery Intervention and Reserve Management on Interest Rates and Exchange Rates in Center Countries" NBER Working Paper 10332, March 2004.

(February 2004b) “Asian Reserve Diversification: Does it Threaten the Pegs?" Global Markets Research.

(June 2004) "A Map to the Revived Bretton Woods End Game: Direct Investment, Rising Real Wages and the Absorption of Excess Labor in the Periphery" Global Markets Research. Also published as "Direct Investment, Rising Real Wages and the Absorption of Excess Labor in the Periphery" NBER Working Paper 10626, July 2004. Published in NBER volume: "Current Account Imbalances: Sustainability and Adjustment" Richard Clarida, ed., May 2007, http://www.nber.org/chapters/c0125

(August 2004) "The US Current Account Deficit: Collateral for a Total Return Swap", Deutsche Bank Global Markets Research. Also in NBER Working Paper 10727.

(December 2004) “The Revived Bretton Woods: Alive and Well” Deutschebank Global Markets Research.

(July 5, 2005) "Savings Gluts, Deficits and Interest Rates: The Missing Link to Europe" Deutschebank Global Markets Research. Also in NBER Working Paper 11520.

(September 20, 2005) "Living with Bretton Woods II", Deutschebank Global Markets Research.

"Life on a Tri-Polar Sphere," NBER volume: International Financial Issues in the Pacific Rim: Global Imbalances, Financial Liberalization and Exchange Rate Policy, July, 2008. http://www.nber.org/chapters/c6978 also NBER Working Paper 11771: Interest Rates, Exchange Rates and International Adjustment, November 2005. June 2007.

"The Two Crises of International Economics", NBER Working Paper 13197,

"Asia, Interest Rates, and the Dollar”, Deutsche Bank, Global Markets Research, March 12, 2008. http://people.ucsc.edu/ mpd/Asia_Interest_rates_and_the_dollar.pdf

"Bretton Woods II Still Defines the International Monetary System", Pacific Economic Review, 14: 3 (2009) pp. 297-311. NBER Working Paper 14731, February 2009. 
Dooley, Michael and Peter Garber, (2005), "Is it 1958 or 1968? Three Notes on the Longevity of the Revived Bretton Woods System," Brookings Papers on Economic Activity 1: 147- 187.

"Global Imbalances and the Crisis: A Solution in Search of a Problem", Vox, March 21, 2009. http://www.voxeu.org/article/what-did-not-cause-global-crisis

"International Imbalances Balance Risk", in Rebalancing the Global Economy: A Primer for Policymaking, Claessens, Stijn et al. eds., Vox Ebook, 2010, pp. 51-3.

Garber, Peter, "What Drives CNH Market Equilibrium?, Council of Foreign Relations, November, 2011. http://www.cfr.org/china/drives-cnh-market-equilibrium/p26292 or http://www.isn.ethz.ch/Digital-Library/Publications/Detail/?lng=en\&id=146209

IMF, People's Republic of China, 2013 Article IV Consultation, IMF Country Report N. 13/211. July 2013. http://www.imf.org/external/pubs/ft/scr/2013/cr13211.pdf

Lucas, Robert, 1990, "Why Doesn't Capital Flow from Rich to Poor Countries?" American Economic Review, Vol. 80 (May), pp. 92-96.

Obstfeld, Maurice \& Rogoff, Kenneth, "Global imbalances and the financial crisis: products of common causes," Proceedings, Federal Reserve Bank of San Francisco, issue Oct, 2009, pages 131-172.

Shi, Audrey and Michael Spencer, “Tracking China's Reforms", Special Report, Deutsche Bank Markets Research, July 15, 2014.

Shi, Kai and Li Nie, "Adjusting the Currency Composition of China's Foreign Exchange Reserve”, International Journal of Economics and Finance, Vol. 4, No.10, pp. 170-9, 2012, Canadian Center of Science and Education, 2012, http://dx.doi.org/10.5339/ijef.v4n10p170.

Singh, Anoop, Malhar Nabar, Papa N'Diaye, eds., China's Economy in Transition, From External to Internal Rebalancing, Washington: IMF, 2013.

Spencer, Michael, "China's final stage of reform”, Global Economic Perspectives, Deutsche Bank Global Markets Research, November 8, 2013, pp. 3-13.

Spencer, Michael, "Demographics and GDP growth in China", Global Economic Perspectives, Deutsche Bank Global Markets Research, November 16, 2012, pp. 3-9.

Spencer, Michael, Lin Li, and Audrey Shi, "2014: a year of economic rebalancing”, Special Report: Deutsche Bank Research, March 28, 2014.

World Bank, "China - Governance, investment climate, and harmonious society : competitiveness enhancement for 120 cities in China", Report \# 37759, Nov 16, 2006.

http://documents.worldbank.org/curated/en/2006/10/7189530/china-governanceinvestment-climate-harmonious-society-competitiveness-enhancement-120-citieschina\#

Zhang, Bin, Xun Wang, and Xiuping Hua, "Nominal and Real Return Rate of China's Foreign Exchange Reserves", International Finance Research Center, World Economy and Politics Research Institute, Chinese Academy of Social Science, Working paper 2010W03, 2010. 


\section{Appendix: Citations for the List of Implications of the Bretton}

\section{Woods II System}

The references below are to pages and chapters in our "Asia, Interest Rates, and the Dollar," 2008. The year refers to the year of the original publication of the referenced chapters.

\section{Domestic Labor Markets and Export-Led Growth}

\section{- Solution to the problem of integration of China}

"The current system...has emerged to solve the fundamental real economic of our time: the integration of...underemployed workers into the global industrial economy." 2004, Direct Investment, p. 84.

"The key global imbalance is the massive excess supply of labor in Asia. From the perspective of an integrated industrial world, we have been living through the equivalent of a labor market Great Depression since China and now also India integrated with the global economy. The unemployed and underemployed labor is regionally concentrated outside the industrial countries, so the impact shows up most clearly in the international accounts." 2008, Keeps Rolling Along, p. 9.

"It is the global economic system's ability to adjust sufficiently to absorb this labor that is the central economic problem of our era. Just as in previous eras dominated by a salient economic problem, the global monetary system has de facto organized itself as a means of solving this one as well." 2008, Keeps Rolling Along, p. 10.

\section{- The system will last ten or more years}

"At some point the current Asian periphery will reach a developmental stage when they will also join the center and float. But that point will not be reached for perhaps ten years..." 2003, Essay, p. 19.

"If the world can absorb politically only the output of an additional 10 million workers per year, then simple arithmetic indicates that this surplus is a force for 20 more years... If it can absorb the surplus faster...then straightforward compounding and linearity assumptions indicate that this will drive the global system ever more relentlessly for the next 12 years." 2004, Direct Investment, p. 86.

- The goal is to employ 200 million workers

"China has about 200 million unemployed or underemployed workers to bring into the modern labor force. For political stability, there is a need for 10-12 million net new jobs per year." 2004, Direct Investment, p. 85.

- The system depended on undervalued exchange rates

"The peripheral countries chose a development strategy of undervalued currencies, controls on capital flows and trade, reserve accumulation, and the use of the center region as a financial intermediary that lent credibility to their own financial systems. In turn, the US lent long term to the periphery, generally through FDI." 2003, Essay, p. 17.

\section{- China split the interests of industrial country labor and capital}

"The solution to the problem came about perhaps by chance--implement the macroeconomic policies outlined above, let foreign financial markets partially intermediate Chinese savings, let foreign capital profit from the strategy, and thereby split the interests of foreign labor and capital to keep open the export markets." 2008, Just Keeps Rolling, p. 11. 
"This would happen through allowing rich country industrial capital access to the cheap labor in the developing country's export sector, thereby splitting the usual protectionist political coalitions." 2005, Introduction, p. 13.

"The foreign investors then become a well-financed and effective lobby to counteract the resistance to the restructuring of the US labor force away from import substitutes." 2004, Direct Investment, p. 92.

- When China joins the other center countries, India will take its place

"...and, most likely, there will be at that time another wave of countries, as India is doing now, ready to graduate to the periphery." 2003, Essay, p. 19.

"The Bretton Woods system does not evolve; it just occasionally reloads a periphery." 2003, Essay, p. 19.

Capital and Current Account Flows

- China must export capital to acquire collateral

"The main point of this paper is that the accounting balance described above does not balance the economic risks faced by participants in international capital markets. We argue below that if current accounts are balanced the periphery's development strategy generates a net exposure for direct investors that will strangle intermediation and limit growth in the periphery. To relax this constraint, the periphery must post collateral and, in fact, must post more collateral the more successful is its development strategy." 2004, Collateral for a Total Return Swap, p. 30.

- Standard textbook model of open economy macroeconomics refuted by uphill capital flow

"All this activism against the ongoing global system has flowed from an implacable faith in the conventional textbook theory of how global capital flows should move. In the most basic implication of the dominant inter-temporal consumption model of international macroeconomics, capital should flow from rich to poor countries. This model is still at the center of academic and official sector thought even though it has rarely worked and even though adherence to its prescriptions delivered disaster after disaster to the emerging markets in the 1970s and 1990s." 2008, Just Keeps Rolling, p. 11.

\section{- Foreign savings pushing in caused low US rates}

"The advent of the system persistently lowered the long term real rate of interest at every stage of the business cycle because of the large scale and growing supply of net savings that emerging market countries were pushing into the industrial countries." 2008, Just Keeps Rolling, p. 6.

"Indeed, the world's pushing of its excess savings into the US was keeping the cost of capital flat in the face of rapid growth." 2004, Alive and Well, p. 111.

"Usually, this rhetoric includes a reference to the role of the US fiscal deficit in reducing net US savings, but that should increase the interest rate. Whatever the size of this effect, it has clearly been more than overcome by the effects of official capital pushing in." 2005, Savings Gluts, p. 122.

\section{Global Real Interest Rates}

- China has a global macroeconomic effect. Real rate not determined by US alone.

"The US is being underwritten by Asia for the foreseeable future." 2003, Essay, p. 23.

"The large US current account deficit has been and is generally expected to be financed by dollar bloc emerging market countries at low real interest rates for many years more, as indicated by low market long-term real interest rates." 2007, Two Crises, p. 50 . 
"The advent of the system persistently lowered the long term real rate of interest at every stage of the business cycle because of the large scale and growing supply of net savings that emerging market countries were pushing into the industrial countries." 2008, Just Keeps Rolling, p. 6.

"We argued in 2003 and early 2004 that due to the nature of the de facto global system nominal and especially real interest rates would remain unusually low at any given phase of the business cycle." 2005, Introduction to 2005 Edition, p. 13.

- China's labor force carries its own raw capital

"We might expect that an increase in the supply of labor would drive real interest rates up, but this labor came with an enormous savings rate and a dead financial system that had served them in the past as a capital destroyer, as it does to this day." 2005, Savings Gluts, p. 117.

\section{Foreign Exchange Reserve Accumulation and Inflation}

- No limit on China's reserve accumulation

"Their appetite for such investments is, for all practical purposes, unlimited because their growth capacity is far from its limit.", 2003, Essay, p. 20.

"In Asia as a whole, a single-minded emphasis on export growth has been supported by a virtually unlimited demand for US financial assets in the form of official reserves." 2003, Essay, p. 22.

“...we see very strong incentives for governments to commit vast resources to the battle to maintain what we have called the revived Bretton Woods System." 2004, Effects of Periphery Intervention, p 74.

\section{- Losses on reserves are a secondary concern}

"...the official sectors are happy to buy US securities to finance the shortfall directly, without regard to the risk/return characteristics of the securities." 2003, Essay, p. 20.

"Most Western macroeconomists with a voice have warned China of this problem. But this has not moved China and it seems clear to us that there are motives for the Chinese government that are more important than optimization of the value of reserves." 2007, Two Crises, p. 52.

"Reserve managers do not behave like private sector fund managers benchmarked to a risk/return calculus--they have other macro motivations." 2004, Alive and Well, p. 112.

"The government's portfolio includes the domestic capital stock as well as foreign exchange reserves; the value of that portfolio should not be maximized locally over its individual subcomponents." 2005, Episodes of Reserve Accumulation, p. 140

\section{- Diversification of reserves is self-defeating}

"Our conclusion is that diversification is inconsistent with a development policy based on export-led growth. An attempt to diversify and maintain dollar cross rates would generate an increase in gross reserve assets and the gross domestic assets required to sterilize the reserve increase." 2004, Effects of Periphery Intervention, p. 74.

"Perhaps more important, pressure from portfolio diversification on the USD/Asian currency cross rate would generate new intervention by Asian central banks to preserve the current dollar rate. Even if this new intervention is less concentrated in dollars than in the past, it can still eventually stabilize the dollar/Asian currency cross rate. But this implies even more rapid growth of gross reserve assets in Asian central 
banks and larger gross private capital inflow to these countries." 2004, Effects of Periphery Intervention, p. 79.

\section{- China would control inflation via raising required reserve ratios}

"there have been claims that undervalued currencies inevitably lead to over-heating and inflation and so must be self-correcting. However, it will take a long time to get to such a point. ...As interim measures, there is room to raise bank reserve requirements or domestic interest rates." 2003, Essay, p. 23.

\section{- Other EM countries would join the system and acquire international reserves}

"More generally, emerging markets now have a choice: they can join Asia in the trade account region or Europe in the capital account region. If they follow the Asian model, they will do whatever it takes to limit exchange rate changes relative to the dollar and to keep their currencies undervalued to spur exports." 2003, Essay, p. 24.

"Other emerging market countries will have to choose which way to go. In Latin America, those impatient for growth through exports will favor free trade, fixed, undervalued rates with the dollar, intervention and capital controls; in short, the Asian model of development." 2003, Essay, p. 24.

\section{Industrial Country Exchange Rates}

\section{- No US exchange rate crisis when the system ends.}

"A 'sudden stop' of private and official capital inflows into the United States would generate a large increase in US interest rates to force investment in the US down to match domestic savings. Moreover, experiences of other countries with similar adjustments suggest that the decline in economic activity could be quite severe. But we argue below that we do not see any material change in the incentives that have held the Bretton Woods II system together to date." 2008, Just Keeps Rolling, p. 5.

"In real terms, the dollar will eventually have to depreciate relative to the renminbi. But most of the adjustment in the US trade account will come as US absorption responds to increases in real interest rates. Slow adjustment in the composition of US output toward traded goods over an extended time period will not require unprecedented dollar depreciation." 2005, Living, p. 97.

\section{- Euro and dollar would move together vs. RMB, except for asynchronous cycles}

"Once the system became fully understood, the floating currencies like the euro would quickly appreciate in real terms against the dollar by the full amount of their long run expected appreciation, but then be trendless." 2008, Keeps Rolling Along, p. 8.

"After a substantial initial appreciation of floating currencies relative to the dollar, the dollar and other floating currencies remain constant relative to each other. ...In real terms, the dollar and the floating currencies will eventually have to depreciate relative to the managed currencies. But most of the adjustment in the US trade account will come as US absorption responds to increases in real interest rates." 2005, Living, p. 97.

\section{- Japan would intervene again.}

"This argument arose in 2003 and early 2004 when Japan intervened in the foreign exchange markets in record amounts in order to pull itself out of its recession and deflation. But when the MoF did cease intervening after Q1 2004, the zero interest rate policy continued, and the private sector picked up the ball and continued exporting capital at a rate of $3.7 \%$ of GDP. Effectively, the intervention had put a floor on the yen, which made for a lower-risk carry trade." 2007. Two Crises, p. 52.

"Japan has ceased its massive intervention since Q1 2004, and the yen has depreciated somewhat against the dollar. Our expectation is that the authorities will return to the 
market if private flows to the US again decline and the yen again appreciates, all the more so if it is tested in another attack." 2005, Savings Gluts, p. 126.

- Euro zone may have to join the system to depreciate the euro.

"An array of central banks and finance ministries has emerged to resist, for their own local reasons, the adjustment that the cyclical fundamentals seem to require. These are mainly the Asian central banks and ministries of finance, but the Federal Reserve is also a major buyer with the fed funds rate set for now at $1 \%$. Even the ECB, if it acts to stem the rise of the euro through direct intervention, may join this group." 2004, Periphery Intervention, p. 75.

"We are witnessing now a shift in global flows of historic proportions. The unwillingness to accept the inevitable downward slide of the USD, due to a massive labor surplus in much of Asia and cyclical fears in Japan, is leading to intervention flows that are unprecedented. Now even the ECB has begun to publicly express concern about appreciation of the euro." 2004, Periphery Intervention, p. 80.

"...we thought that Europe would take a lot of pain before overcoming ECB reluctance, but it now has become much more likely. Nearly every week brings new veiled threats of action from the political authorities or statements of anguish from ECB officials. .... But Europe cannot afford to absorb even more deflationary pressure. When Japan and the rest of Asia resume massive sales of their currencies in the next market test of the system, the Europeans may be forced to join them in supporting the dollar and the US deficit as the euro floating regime comes to an end." 2004, Alive and Well, p. 113.

\section{Labor Market Supply Effects}

- US would take no serious action to protect its industrial workers

"The solution to the problem came about perhaps by chance--implement the macroeconomic policies outlined above, let foreign financial markets partially intermediate Chinese savings, let foreign capital profit from the strategy, and thereby split the interests of foreign labor and capital to keep open the export markets." 2008, Keeps Rolling Along, p. 11.

"The mechanism that regulates the mobilization is a cross-border transfer to countries like the United States that are willing to restructure their labor markets to accommodate the rapid growth of industrial employment in Asia." 2004, Direct Investment, p. 85.

"...it is clear to us that industrialization of the periphery requires a fundamental restructuring of the labor force in the center. While this creates tremendous aggregate benefits for both countries, established industries and their workers in the center are displaced. No country has found a workable way to compensate its own losers. So a surplus must be generated and properly allocated to provide additional incentives to overcome protection." 2004, Direct Investment, p. 85.

"The political costs of adjusting displaced labor and capital in the importing country have been compensated. This co-opts attempts to use commercial policy to freeze out the exports that are vital to the development policy." 2004, Direct Investment, p. 89.

- Europe would take action to protect its industrial workers.

"But the US is open; Europe is not. Europe could not absorb the flood of goods, given its structural problems and in the face of absorbing Eastern Europe as well." 2003, Essay, p. 23.

- The RMB exchange rate controls the release of rural labor into the cities.

"An initially low but rising currency also helps control the rate of migration from the countryside to urban areas by keeping the relative price of domestic agricultural 
output high. The typical problem in emerging markets is to avoid offering too high an industrial wage while still inducing resource transfers to industry and restraining migration out of the countryside to a rate consistent with capital formation in the industrial sector." 2005, Savings Gluts, p. 125.

"It is instead using a real undervaluation of its currency to limit urban migration and to subsidize rapid industrialization and absorption of unemployed labor." 2005, Episodes of Reserve Accumulation, p. 140.

Transition to System's End.

\section{- Gradual RMB appreciation}

"But intervention by Asian governments is sufficient to manage strictly the dollarrenminbi exchange rate. Intervention will not keep the renminbi undervalued forever, but it can extend the adjustment period. As we have argued elsewhere, the optimal path (from China's perspective) for Asian real exchange rates is a gradual appreciation toward their new long run values." 2005, Living, p. 103.

"First, for some years, Asian governments can and will manage the real dollar value of their currencies. They can do so because capital controls make Asian domestic assets imperfect substitutes for US and Euroland assets in private portfolios.... Their desire to maintain the system will also erode as their surplus labor is absorbed. But they will manage rates as long as they can because undervaluation is an important part of their development strategy." 2005, Living, p.103.

\section{- Gradual lifting of controls}

"Their ability to manage their real exchange rate will erode over time as capital controls become less effective and their domestic asset markets are integrated with international capital markets. Their desire to maintain the system will also erode as their surplus labor is absorbed." 2005, Living, p. 103.

"An important constraint on capital inflows into China is the underdeveloped and bankrupt domestic financial market. As the industrial sector grows and that sector lobbies for a better domestic financial system, the whole fabric of financial repression will unravel. But this takes time." 2005, Episodes of Reserve Accumulation, p. 129.

- China would join the other center countries in a floating exchange rate system

"At some point, the current Asian periphery will reach a developmental stage when they also will join the center and float." 2003, Essay, p.19. 
